\title{
CONSPIRACY TO DEFRAUD THE UNITED STATES
}

\author{
ABRAHAM S. GOLDSTEIN $\div$
}

IT has long been our boast that we class as crimes only those acts that are recognizably dangerous to the community. Never, the maxim has it, do we punish an evil intent alone. ${ }^{1}$ Though much of contemporary theory would strip "act" of any significance beyond that of "muscular contraction" and would focus instead upon the state of mind of the accused, the traditional conception of "act" continues its hold upon the imagination of men and upon legal doctrine. It expresses today, as it did three centuries ago, the feeling that the individual thinking evil thoughts must be protected from a state which may class him as a threat to its security. Rooted in skepticism about the ability either to know what passes through the minds of men or to predict whether antisocial behavior will follow from antisocial thoughts, the act requirement serves a number of closely-related objectives: it seeks to assure that the evil intent of the man branded a criminal has been expressed in a manner signifying harm to society; that

†Associate Professor of Law, Yale Law School. The author is indebted to Thomas Schwab of the District of Columbia Bar and to Peter C. Alegi of the third-year class of the Yale Law School for research done by them in connection with portions of this Article.

1. "[T]he imagination of the mind to do wrong, without an act done, is not punishable in our law." Hales v. Petit, 1 Plow. 253, 259, 75 Eng. Rep. 387, 397 (C.B. 1562). See Hitchler, The Physical Element of Crime, 39 Dick. L. Rev. 95, $95-97$ (1934) (collecting statements and authorities); 1 Bishop, CRIMINAL LAW $\$ 204$ (9th ed. 1923); 4 Blackstone, Commentaries *21 ("[A]s no temporal tribunal can search the heart, or fathom the intentions of the mind, otherwise than as they are demonstrated by outward actions, it therefore cannot punish for what it cannot know.") ; Perkins, A Rationale of Mens Rea, 52 HARv. L. Rev. 905, 907 (1939).

It was not always so. "To compass or imagine the death of the king," for example, was treason under 21 Rich. 2, c. 3. (1397) and subsequent statutes. But the "dangers to security" threatened by such laws brought about their repeal and the requirement that thoughts be classed as treason only if they were evidenced by some overt act. "But the overt act need not have operated in the least to effectuate the harm sought." HaII, Criminal Law 69-71 (1947).

"Act" has ordinarily been taken to mean the infliction of the social harm at which the statute creating the crime is directed, as distinguished from the mental state or "intent" of the actor. Both "act" and "intent" are necessary parts of conventional crimes, though borderline crimes exist in which social harm is held to stem from "omissions" or "words" or "possession," and in which use of the word "act" may be misleading. See generally, concerning the act-intent distinction, $i d$. at 13-14; Williams, Criminal Law $\$ \S 1-8$ (1953); Model Penal Code $\$ \S 2.01-.03$, comments (Tent. Draft No. 4, 1955). On the other hand, the public welfare offenses are so predominantly concerned with the "act" part of the formula that little or no attention is paid to the mental state of the actor. See Morissette v. United States, 342 U.S. 246, 252-63 (1952). An interesting comparison may be found in the almost exclusive concern with mental processes illustrated by sexual psychopath commitment statutes, under which persons may be incarcerated for extended periods, albeit as "patients" rather than as "criminals." See, e.g., ILI. REv. STAт. ch. 38 , §§ 820.01-825g (1957). 
there is no longer any substantial likelihood that he will be deterred by the threat of sanction; and that there has been an identifiable occurrence so that multiple prosecution and punishment may be minimized.

More than any other important crime, conspiracy impinges on the act requirement. ${ }^{2}$ It does so in ways significantly different from the other inchoate crimes. The law of attempts, for example, searches for the point at which criminal intent has proceeded beyond "preparatory" action and has reached the "commencement of the consummation" of the crime. ${ }^{3}$ The law of solicitations may substitute for this careful plotting of the line between intent and act a context which indicates the probability that aggressive statement will be transformed into harmful action. ${ }^{4}$ In contrast, conspiracy doctrine comes closest to making a state of mind the occasion for preventive action against those who threaten society but who have come nowhere near carrying out the threat. No effort is made to find the point at which criminal intent is transformed into the beginnings of action dangerous to the community. Instead, the mystique of numbers, of combination, becomes the measure of danger. Even when a statute requires an overt act "to effect the object of the conspiracy," as in federal law, it may be a completely innocent one which indicates little or nothing of the kind of injury to society which the conspiracy seeks to bring about. 5 The agreement to accomplish the prohibited purpose furnishes, without more, the basis for criminal liability. ${ }^{6}$

2. For intraductory discussions of conspiracy, see Williams, Crininal Law $\S \S$ 155-69 (1953); Perkins, Criminal Law 527-49 (1957).

3. People v. Miller, 2 Cal. 2d 527, 530, 42 P.2d 308, 309 (1935) ; People v. Rizzo, 246 N.Y. 334, 337, 158 N.E. 888, 889 (1927); Hall, Criminal Law 99-101 (1947) ; Holares, The Common Law 68-69 (1881); Willyams, Criminal Law $\$ \S 144-46$ (1953); see Arnold, Criminal Attempts-The Rise and Fall of an Abstraction, 40 YALE L.J. 53 (1930). There is no general federal crime of attempt, though it is incorporated, in modified form, as an element of some specific offenses. See, e.g., Spies v. United States, 317 U.S. 492, 498-99 (1943).

4. As to solicitation, sometimes called incitement, see State v. Schleifer, 99 Conn. 432, 121 Atl. 805 (1923), rev'd on other grounds, 102 Conn. 708, 130 Atl. 184 (1925) (indicating also that solicitation is sometimes classed as an attempt); Williams, Crrminal Law $\S \S$ $136-39$ (1953) ; Blackburn, Solicitation to Crimes, 40 W. VA. L.Q. 135 (1933) ; Curran, Solicitation: A Substantive Crime, 17 Mrnn. L. Rev. 499 (1933) ; Hitchler, Solicitations, 41 Dick. L. REv. 225 (1937); Annot., 35 A.L.R. 961 (1925). As with attempt, see note 3 supra, there is no federal statute creating a general crime of solicitation.

5. Exactly what the federal courts construe the "overt act," note 7 infra, to mean is unclear. On its face, the requirement is additional to conspiracy as it was known at common law. See Fiswick v. United States, 329 U.S. 211, 216 n.4 (1946) ; Bryan, The DeveropMIENT OF THE English LaW of Conspiracr 82 (1909). Some of the decisions view it only as affording a locus penitentiae-a point until which the abandonment of the conspiracy may occur and from which the statute of limitations may run. United States v. Britton, 108 U.S. 199, 204-05 (1883) ; United States v. Manton, 107 F.2d 834, 838 (2d Cir.), cert. denied, 309 U.S. 664 (1939) ; cf. Asgill v. United States, 60 F.2d 780, 785 (4th Cir. 1932). Others treat the "overt act" requirement as an element of the offense because it must be proved before conviction may be had. Hyde v. United States, 225 U.S. 347, 359 (1912) ; Huff v. United States, 192 F.2d 911, 914-15 (5th Cir. 1951), cert. denied, 342 U.S. 946 (1952); Smith v. United States, 92 F.2d 460, 461 (9th Cir. 1937). Since, however, the 
If the prohibited purpose is clearly set forth in the conspiracy statute, the difficulties are solely those involved in applying the concept of an agreement. When, however, unlawful purpose is vaguely stated, the contours of "conspiracy" become ever more vague, and the dividing line between intent, now designated "purpose," and act, now termed "agreement," tends to disappear. Added to the problems inherent in a concept created to deal with potential antisocial action are new ones which arise when it is not at all clear what kind of antisocial action is threatened.

The federal conspiracy statute brings the problem into sharp relief. Though it purports to specify the purposes which transform mere agreements into crime -prohibiting conspiracy either "to commit any offense against the United States, or to defraud the United States, or any agency thereof in any manner or for any purpose"7 - it introduces through the phrase "defraud the United

overt act proved at trial may be one which has not been set forth in the indictment, United States v. Negro, 164 F.2d 168, 172-73 (2d Cir. 1947), it is difficult to class it as an element of the offense, in any conventional sense; the indictment ordinarily must charge each of the elements of a crime. See Note, 61 HARv. L. REv. 705 (1948). Whatever the rationale of the "overt act" requirement, clearly the act need not be one that is criminal or illegal or otherwise proscribed. Indeed, it may be innocent in all respects, except for the fact that it stems from the agreement. Braverman v. United States, 317 U.S. 49, 53 (1942); United States v. Rabinowich, 238 U.S. 78, 86 (1915) ; Bartoli v. United States, 192 F.2d 130, 132 (4th Cir. 1951) ; Carlson v. United States, 187 F.2d 366, 370 (10th Cir.), cert. denied, 341 U.S. 940 (1951); United States v. Johnson, 165 F.2d 42, 45 (3d Cir. 1947), cort. denticd, 332 U.S. 852 (1948).

6. Braverman v. United States, 317 U.S. 49, 53-54 (1942) ; Troutman v. United States, 100 F.2d 628, 632 (10th Cir. 1938); United States v. Mazzochi, 75 F.2d 497, 498 (2d Cir. 1935) ; see Hyde v. United States, 225 U.S. 347, 387-88 (1912) (dissenting opinion of Holmes, J.) (attempt and conspiracy contrasted) ; Krulewitch v. United States, 336 U.S. 440, 447-48 (1949) (concurring opinion of Jackson, J.) ; Harno, Intent in Crininal Conspiracy, 89 U. PA. L. Rev. 624, 629-35 (1941).

7. 18 U.S.C. $\$ 371$ (1952). In full, the statute reads:

If two or more persons conspire either to commit any offense against the United States, or to defraud the United States, or any agency thereof in any manner or for any purpose, and one or more of such persons do any act to effect the object of the conspiracy, each shall be fined not more than $\$ 10,000$ or imprisoned not more than five years, or both.

If, however, the offense, the commission of which is the object of the conspiracy, is a misdemeanor only, the punishment for such conspiracy shall not exceed the maximum punishment provided for such misdemeanor.

The federal criminal code contains several other conspiracy provisions; but, except for that in the Civil Rights Acts, 18 U.S.C. $\$ 241$ (1952), they are more specific than $\$ 371$. E.g., 18 U.S.C. $\$ \$ 286,372,757,956,1201,1792,2153,2154,2192,2271,2384$ (1952).

For a description and collection of state statutes dealing with conspiracy, see Note, 68 HaRv. L. Rev. 1056 (1955). Typical of the state enactments is N.Y. PEN. LAw § 580, which provides:

If two or more persons conspire:

1. To commit a crime; or,

2. Falsely and maliciously to indict another for a crime, or to procure another to be complained of or arrested for a crime; or, 
States" a concept every bit as shadowy as common law conspiracy. ${ }^{8}$ In combination, "conspiracy" and "defraud" have assumed such broad and imprecise proportions as to trench not only on the act requirement but also on the standards of fair trial and on constitutional prohibitions against vagueness and double jeopardy. Yet the difficulties of "conspiracy to defraud the United States" have gone virtually unrecognized by commentators ${ }^{9}$ and courts. The

3. Falsely to institute or maintain an action or special proceeding; or,

4. To cheat and defraud another out of property, by any means which are in themselves criminal, or which, if executed, would amount to a cheat, or to obtain money or any other property by false pretenses; or,

5. To prevent another from exercising a lawful trade or calling, or doing any other lawful act, by force, threats, intimidation, or by interfering or threatening to interfere with tools, implements, or property belonging to or used by another, or with the use or employment thereof; or,

6. To commit any act injurious to the public health, to public morals, or to trade or commerce, or for the perversion or obstruction of justice, or of the due administration of the laws,

Each of them is guilty of a misdemeanor.

For a discussion of a contemporary application of the common-law concept of conspiracy, see Note, 15 U. CHI. L. REv. 939 (1948).

8. Fraud, like many familiar concepts, is one which seems to have a perfectly obvious meaning until we try to define it. ...

Perhaps one of the reasons why courts and writers have had so much difficulty in defining fraud is that it is not a tool designed for a single use. Like domicile and possession it is a multiple-purpose concept and its inner meaning varies according to the function it is put to serve. In the law of Torts there is a common law action of deceit which is based upon fraud. As used in this connection fraud connotes the making of a misrepresentation of a material fact, with knowledge of its falsity (scienter) and with the intention of having the other person rely upon it. If the other person reasonably relies upon it to his detriment he has a tort action for damages against the person making the false representation. Equity will grant rescission of a contract induced by the same type of fraud, but equity has gone further: equity no longer requires scienter. In other words, as used in some of the equity cases fraud may be predicated upon innocent misrepresentation. These two types of situation are rather well defined, but there is another large group of cases where courts and writers feel that there has been overreaching, an unfair advantage taken, and frequently dub this kind of conduct "fraudulent." This broader conception more closely approaches the layman's conception of fraud as consisting of any kind of trickery or unfair conduct. Professor Patterson has characterized it as the "shotgun, or rather shrapnel" definition of fraud. In order to differentiate this loose meaning of fraud from the more discreet ones previously discussed some writers have applied to it various qualifying adjectives such as "legal" or "constructive" fraud. Others, to distinguish fraud as used in the discreet sense from fraud as used in the loose sense have characterized it as "positive" or "actual" fraud.

Green, Fraud, Undue Influence and Mental Incompetency, 43 CoLuM. L. REv. 176, 17779 (1943).

9. Among the few allusions to the "defraud" statute are the passing references in Arens, Conspiracy Revisted, 3 Buffalo L. Rev. 242, 247 (1954); Sayre, Criminal Conspiracy, 35 HARV. L. REv. 393, 425 (1922). 
federal cases leave the impression that the large problems of defining the crime have long been resolved, with only procedural and tactical minutiae remaining for discussion. ${ }^{10}$ Nothing could be further from the truth. An examination first of "conspiracy" and then of "defraud the United States" will demonstrate their peculiar susceptibility to a kind of tactical manipulation which shields from view very real infringements of basic values of our criminal law.

\section{Conspiracy Examined}

"Conspiracy" has been a favorite of prosecutors for centuries. The reasons for its popularity lie partly in history, partly in the increased punishment potential afforded by its status as a separate crime. Most potent of all, however, has been the tactical advantage it brings to the prosecutor. By charging "conspiracy," he can reach persons who might escape conviction if they were proceeded against separately or if they were charged with accomplished harm to the community. It is in this realm of trial tactics that "agreement" and "unlawful purpose" affect each other most. .

\section{The Dynamics of Conspiracy}

The agreement represents the actualization of the intent contemplated by the act-intent maxim. It is the "act" which expresses in concrete form the threat to society of an intent shared by two or more persons. Vicarious liability is imputed and hearsay admitted, statute of limitations tolled and venue attained -all by virtue of the terms of that agreement. ${ }^{11}$

10. Apart from the positions occasionally taken in concurring or dissenting opinions, see, c.g., cases cited note 13 infra, Supreme Court reversals of conspiracy convictions are usually attributable to some defect of allegation or proof discovered in the record rather than to dissatisfaction with the crime itself-and this despite the Court's statement that it "will view with disfavor attempts to broaden the already pervasive and wide-sweeping nets of conspiracy prosecutions." Grunewald v. United States, 353 U.S. 391,404 (1957); see Krulewitch v. United States, 336 U.S. 440 (1949).

11. Each member of a conspiracy is liable for the acts of other members which are within the scope of the agreement among them, but only while that agreement is still operative. Pinkerton v. United States, 328 U.S. 640, 645-48 (1946). Statements made by any alleged conspirator are attributed to his coconspirators on the same basis. Delli Paoli v. United States, 352 U.S. 232, 237 (1957) ; Lutwak v. United States, 344 U.S. 604, 617-19 (1953) ; Levie, Hearsay and Conspiracy, 52 MrсH. L. Rev. 1159 (1954). Before any defendant may be charged with the acts and statements of his fellow defendants, however, the jury must find that evidence of the conspiracy exists independent of the hearsay acts and statements. United States v. Schneiderman, 106 F. Supp. 906, 936-37 (S.D. Cal. 1952).

The statute of limitations begins to run from the last overt act committed "to effect the object of the conspiracy." Fiswick v. United States, 329 U.S. 211, 216 (1946). "[T]he crucial question [therefore] . .. is the scope of the conspiratorial agreement, for it is that which determines both the duration of the conspiracy, and whether the act relied on as an overt act may properly be regarded as in furtherance of the conspiracy." Grunewald v. United States, 353 U.S. 391, 397 (1957) ; see Brown v, Elliott, 225 U.S. 392 (1912).

Venue attaches at the place either of the agreement or of any of the overt acts committed 
Yet "agreement" is almost as much a theoretical construct as the "intent" it is supposed to carry over the threshhold from fancy to fact. Indeed, in most cases, it is proved by the very same evidence from which intent will be inferred. Thus, instead of anchoring intangible intent to a tangible act, the law of conspiracy makes intent an appendage of the equally intangible agreement. By pouring the same proof into the mold of "agreement" and by calling that "agreement" an "act"- - passive though it may be-courts foster the already elaborate illusion that conspiracy reaches actual, not potential, harm.

The illusory quality of agreement is increased by the fact that it, like intent, must inevitably be based upon assumptions about what people acting in certain ways must have had in mind. ${ }^{12}$ It is ordinarily fashioned by a jury out of bits and pieces of circumstantial evidence, usually styled "overt acts," offered to prove that two or more persons are (or were) pursuing a given unlawful purpose. The sensation that the proof consists of little more than "bits and pieces" is, of course, intensified by the fact that acts and statements of each of several defendants are being offered into evidence as imputable to each of the other defendants. And overshadowing the entire proceeding is the uneasy feeling that the evidence may be taking the form cast for it in the indictment quite as much because the parties are seated together in the courtroom as defendants in a common trial as because they did, in fact, agree. ${ }^{13}$ This is not to say that words of caution are not uttered by judge to jury. Indeed, conspiracy cases

pursuant to the agreement. Hyde v. United States, 225 U.S. 347, 356-67 (1912) ; Hyde v. Shine, 199 U.S. 62, 76-77 (1905). The problem, once again, is to determine the scope of the agreement so that the loci of the overt acts may be identified.

12. See Glasser v. United States, 315 U.S. 60, 80 (1942); Eastern States Retail Lumber Dealers' Ass'n v. United States, 234 U.S. 600, 612 (1914); Wellman v. United States, 227 F.2d 757, 768 (6th Cir. 1955), vacated and remanded per curiam, 354 U.S. 931 (1957) ; Madsen v. United States, 165 F.2d 507, 511 (10th Cir. 1947); United States v. Randall, 164 F.2d 284, 288-89 (7th Cir. 1947), cert. denied, 333 U.S. 856 (1948) ; United States v. Manton, 107 F.2d 834, 839 (2d Cir. 1939), cert. denied, 309 U.S. 664 (1940); Lefco v. United States, 74 F.2d 66, 68-69 (3d Cir. 1934) ; United States v. Schneiderman, 106 F. Supp. 892, 900-01 (S.D. Cal. 1952), aff'd sub nom. Yates v. United States, 225 F.2d 146 (9th Cir. 1955), rev'd, 354 U.S. 298 (1957) ; Von Moltke v. Gillies, 332 U.S. 708, 727-28 (1948) (concurring opinion); Note, The Conspiracy Dilemnna, 62 HARv. L. Rev. 276, 278-79 (1948) (collecting cases); Note, Guilt by Association, 17 U. Cसr. L. REv. 148, 153 (1949).

13. Note the well-known comment of Justice Jackson on why "conspiracy" has become a prosecutor's favorite:

When the trial starts, the accused feels the full impact of the conspiracy strategy. Strictly, the prosecution should first establish prima facie the conspiracy and identify the conspirators, after which evidence of acts and declarations of each in the course of its execution are admissible against all. But the order of proof of so sprawling a charge is difficult for a judge to control. As a practical matter, the accused often is confronted with a hodgepodge of acts and statements by others which he may never have authorized or intended or even known about, but which help to persuade the jury of existence of the conspiracy itself. In other words, a conspiracy often is proved by evidence that is admissible only upon assumption that conspiracy existed. The naive assumption that prejudicial effects can be overcome by instructions to the 
are among the rare instances in which trial judges ask juries to be mindful of the vagaries of the process in which they are participating.

More important, however, jurors are also told that the existence of a conspiracy may be inferred from the unfolding of events over an extended period of time and that, though evidence like unexplained meetings of defendants is insufficient in and of itself, such evidence must be used if the crime is ever to be discovered. ${ }^{14}$ Judicial folklore is also shared. Conspirators, juries are advised, do not shout their plans from the roof-tops. Nor do they cast them in written form or announce them in the presence of witnesses. ${ }^{15}$ The

jury, $c f$. Blumenthal v. United States, 332 U.S. 539, 559, all practicing lawyers know to be unmitigated fiction. . . .

A co-defendant in a conspiracy trial occupies an uneasy seat. There generally will be evidence of wrongdoing by somebody. It is difficult for the individual to make his own case stand on its own merits in the minds of jurors who are ready to believe that birds of a feather are flocked together. If he is silent, he is taken to admit it and if, as often happens, co-defendants can be prodded into accusing or contradicting each other, they convict each other. There are many practical difficulties in defending against a charge of conspiracy which I will not enumerate.

Krulewitch v. United States, 336 U.S. 440, 453-54 (1949) (concurring opinion of Jackson, J.). See Pinkerton v. United States, 328 .U.S. 640, 650 (1946) (Rutledge, J., dissenting in part).

See also Delli Paoli v. United States, 352 U.S. 232, 246 (1957) (dissenting opinion by Frankfurter, J.) ; Darrow, The Story of My Life 64, 144-45 (1932) ; KenNy, OUTLINES of CRIMINAL LAW $\$ 454$ (1952) (indicating that English application of the conspiracy concept creates similar problems); O'Brian, Loyalty Tests and Guilt by Association, 61 HaRv. L. Rev. 592, 599-600 (1948); O'Dougherty, Prosecution and Defense Under Conspiracy Indictments, 9 Brookdyn L. REv. 263 (1940).

14. See generally Direct Sales Co. v. United States, 319 U.S. 703, 714 (1943) ; United States v. Falcone, 311 U.S. 205, 210 (1940); Hyde v. United States, 225 U.S. 347, 371 (1912) ; United States v. Dellaro, 99 F.2d 781, 783 (2d Cir. 1938) ; Asgill v. United States, 60 F.2d 780, 785 (4th Cir. 1932) ; United States v. Foster, 9 F.R.D. 367, 377-78 (S.D. N.Y. 1949), aff'd sub nom. United States v. Dennis, 183 F.2d 201 (2d Cir. 1950), aff'd, 341 U.S. 494 (1951) ; State v. Buchanan, 5 H. \& J. 317, 360 (MId. 1821).

15. "Conspirators do not go out upon the public highways and proclaim their purpose; their methods are devious, hidden, secret and clandestine." Marrash v. United States, 168 Fed. 225, 229 (2d Cir. 1909) ; see Radin v. United States, 189 Fed. 568, 570 (2d Cir.), ccrt dinicd, 220 U.S. 623 (1911). Judge Weinfeld's charge in United States v. Bruswitz, Indictment No. C-140-219, S.D.N.Y., aff'd, 219 F.2d 59, 62-63 (2d Cir.), cert. denied, 349 U.S. 913 (1955), is also typical. After describing conspiracy as "an offense of grave character," he continues, "it is almost always characterized by secrecy, rendering detection difficult and requiring much time for its discovery." See also United States v. Lancaster, 44 Fed. 896, 902 (C.C.W.D. Ga. 1891). For Supreme Court commentary on the connotations of "conspiracy," see Krulewitch v. United States, 336 U.S. 440, 448 (1949) (concurring opinion of Jackson, J.) : "The crime comes down to us wrapped in vague but unpleasant connotations. It sounds historical undertones of treachery, secret plotting and violence on a scale that menaces social stability and the security of the state itself." See also Blumenthal v. United States, 332 U.S. 539, 557 (1947).

From one commentator's viewpoint, "this fear of conspiracy, frequently expressed in terms of sinister characters meeting in dark corners and secretly plotting organized crimi- 
net effect of such commentary is to free juries from the automatic compliance with "law" which instructions ordinarly demand and to invite a "guilty" verdict on less evidence than might otherwise be required.

This relaxation of standards of proof tends also to affect the criteria of relevance used by the trial judge to determine the admissibility of items of circumstantial evidence. Since it is he and his fellow judges who have impressed conspiracy with a clandestine air, it is not surprising to find the judge allowing considerable latitude in proof-making to those who would discover secretive plotting. Although this latitude is supposedly kept within bounds by the allegations of the indictment, the limitation is illusory. Rules which permit the crime to be charged in little more than the language of the statute, ${ }^{16}$ under which amplification by way of bill of particulars is grudgingly granted ${ }^{\mathbf{1 7}}$ and which allow proof of acts evidencing the agreement other than those set forth in the indictment ${ }^{18}$ tend, in ultimate effect, to make the criterion of relevance applied by the judge as broad or as narrow as the statutory definition of the crime.

The criterion of relevance in a trial for conspiracy to murder or to rob or to effectuate any other crime having a relatively fixed content is not substantially different from that which prevails in the trial of the substantive offense. When, however, the object of the conspiracy is virtually indefinable, as is the case with "conspiracy to defraud the United States," defense counsel is placed in the unenviable position of not knowing what the defendant is supposed to have agreed to do. As a result, he is handicapped in making intelligent objections to the fragments of evidence offered by the prosecutor as bases from which the agreement may be inferred. And the trial judge is unable to deal intelligently with objections, when made. The trial becomes a vehicle for constant shaping and forming of the crime, through colloquies among court and counsel, as each new item of evidence is offered by the prosecution to fill out an agreement whose scope will be unknown until the entire process is completed. Expanding and contracting at each stage of the proceedings is the agreement itself, its nature, at all times, the sole criterion of the relevance of each of the items of evidence offered to prove that it exists at all.

nality, depicts the climate of thinking which has nourished the inordinate growth of the conspiracy doctrine and the development of an intricate network of subtle rules, loose practices and nebulous criteria of proof." Klein, Conspiracy-The Prosecutor's Darling, 24 Brookly N L. Rev. 1, 4-5 (1957).

16. Rivera v. United States, 57 F.2d 816,819 (1st Cir. 1932) ; see Wong Tai v. United States, 273 U.S. 77, 81 (1927). Forms 1-11, appended to the Federal Rules of Criminal Procedure, illustrate the simplicity of modern criminal pleading.

17. See Annot., 5 A.L.R.2d 444 (1949), and consider the extent to which the cases there discussed demonstrate a tendency on the part of trial judges to use the discretion allowed them by appellate courts as a license to deny requests for particulars. See also United States v. Metropolitan Leather \& Findings Ass'n, 82 F. Supp. 449, 454 (S.D.N.Y. 1949).

18. United States v. Negro, 164 F.2d 168, 173 (2d Cir. 1947). 


\section{The Group Danger Rationale}

That a crime marked by so little procedural and evidentiary rigor would prove a favorite of prosecutors was to be expected. It was, of course, unlikely that so gross a justification as expediency would be offered for treating conspiracy as a crime punishable separately from, and in addition to, the sanction which could be imposed for accomplishment of the unlawful purpose. A more elaborate rationale was fashioned, principally in the cases which refused to hold that conspiracy merged in the completed conduct which was its object. ${ }^{10}$ Building on the assumption that a group is more to be feared than individuals acting separately, courts concluded that a plan by two or more persons to commit crime brings with it an increased likelihood that: the participants will reinforce each other's determination to carry out the criminal object; the object will be successfully attained; the extent of the injury to society will be large; those who commit it will escape detection; and the group's planning will have a long-term educative effect on its members, with schooling in crime the result. ${ }^{20}$ The potency of some or all of these theories is attested by the fact that conduct is occasionally classed as criminal when planned by two which would not be a crime even if accomplished by one. ${ }^{21}$ "Conspiracy to defraud

19. See cases cited note 20 infra; Annot., 37 A.I.R. 778 (1925); Annot., 75 A.L.R. 1411 (1931). For a discussion of the theory of merger-now almost universally rejectedunder which conspiracy is not treated as a separate crime if its object has been accomplished, see Williams, Criminal Law \& 162 (1953) ; Perkins, Criminal Law 53334 (1957). Note, also, the means sometimes adopted by the English courts to revive merger, sub rosa, by requiring the prosecutor to elect between conspiracy and the substantive offense. Regina v. Burch, 176 Eng. Rep. 622, 624 (N.P. 1865), cited in Wrltrams op. cit. supra $\$ 162$, at 530. A similar result may be achieved, even if convictions for both conspiracy and the substantive offense are allowed, through the trial judge's use of concurrent sentences. The potential for cumulating sentences continues to exist, however. Professor Donnelly of the Yale Law School has proposed that there be no conviction and sentence for both the conspiracy and the completed crime. Donnelty, Code of CoRrection fOR the ComimonWealth of Puerto Rico $\$ 43$ (Preliminary Draft, July 1957). To the same effect is Wis. StAт. $\$ 939.72$ (1955).

20. Pinkerton v. United States, 328 U.S. 640, 644 (1946), quoting from United States v. Rabinowich, 238 U.S. 78, \&8 (1915). Compare Justice Douglas's acceptance of the conventional conspiracy rationale in Pinkerton with his criticism of "guilt by association" in the civil liberties context of Joint Anti-Fascist Comm. v. McGrath, 341 U.S. 123, 178-79 (1951) (concurring opinion). See also Woods v. United States, 240 F.2d 37, 41 (D.C. Cir. 1956), cert. denied, 353 U.S. 941 (1957) ; Lisansky v. United States, 31 F.2d 846, 849-50 (4th Cir.), cert. denied, 279 U.S. 873 (1929); Sneed v. United States, 298 Fed. 911, 912-13 (5th Cir.), cert. denied, 265 U.S. 590 (1924) ; Thomas v. United States, 156 Fed. 897, 902 (8th Cir. 1907) ; United States v. Lancaster, 44 Fed. 896, 899 (C.C.W.D. Ga. 1891) (charge to jury); United States v. Weinberg, 129 F. Supp. 514, 524 (M.D. Pa. 1955) ; People v. Comstock, 147 Cal. App. 2d 287, 305 P.2d 228 (1956) ; Commonwealth v. Judd, 2 Mass. 329, 336 (1807); Note, The Conspiracy Dilemma: Prosecution of Group Crine or Protection of Individual Defendants, 62 HaRv. L. REv. 276, $283-84$ (1948); Note, Criminal Conspiracy: Bearing of Overt Acts Upon the Nature of the Crime, 37 HARV. L. REv. 1121, 1123 (1924).

21. See notes $27-32$ infra and accompanying text. 
the United States" is the outstanding example, for federal law knows no substantive crime of "defrauding the United States."

Though these assumed dangers from conspiracy have a romantically individualistic ring, they have never been verified empirically. It is hardly likely that a search for such verification would end in support of Holdsworth's suggestion that combination alone is inherently dangerous. ${ }^{22}$ This view is immediately refuted by reference to our own society, which is grounded in organization and agreement. More likely, empirical investigation would disclose that there is as much reason to believe that a large number of participants will increase the prospect that the plan will be leaked as that it will be kept secret; or that the persons involved will share their uncertainties and dissuade each other as that each will stiffen the others' determination. Most probably, however, the factors ordinarily mentioned as warranting the crime of conspiracy would be found to add to the danger to be expected from a group in certain situations and not in others; the goals of the group and the personalities of its members would make any generalization unsafe and hence require some other explanation for treating conspiracy as a separate crime in all cases.

What does seem to lie at the root of conspiracy's continued independent status is the degree of deliberateness of antisocial tendency it seems to evidence. Since conspiracy ordinarily involves deliberate plotting to commit a crime at some time in the future, it requires a staying power of criminal bent greater than that needed for the kind of intent which virtually coincides with the criminal act. Like assault with a dangerous weapon, conspiracy might therefore be described as a crime of aggravation. Here, however, the group is the instrument which marks the unlawful purpose as one more deliberately entertained and more likely to be accomplished. The distinction between the two cases is that, in assault, the aggravating factor is given content on a case-bycase basis. Not all weapons are "dangerous" and not all juries will find even weapons which appear dangerous to be so. Under conspiracy law, on the other hand, all groups are conclusively presumed to render the proscribed object more attainable, the criminal intent more firmly held and the consequent imposition of additional punishment justifiable. Ordinarily, no effort is made to determine from the facts of each case or class of case the essential issue of whether society has more to fear from the plan of two than from the deed of one.

\section{"Defraud the United States"}

The federal crime of conspiracy depends for its meaning not upon the common-law development of that concept but upon the unlawful purposes specified in the conspiracy statute itself. The agreement must contemplate either the commission of "any offense against the United States" or the defrauding of

22. Holdsworth, Conspiracy and Abuse of Legal Process, 37 L.Q. Rev. 462, 467 (1929). But cf. 11 N.Y.U.L.Q. 469,470 (1934) (suggesting that the law of conspiracy favors corporations over individuals in that a corporation may do with impunity what a group of individuals may not). 
the United States "in any manner or for any purpose." Since the first of these classes of unlawful objects incorporates by reference every statutory "offense," 23 it follows that all frauds which have been made substantive offenses can be reached under the language of the first half of the statute. What, then, is left to the second half? At first blush, it could be said to reach all "offenses" which involve frauds against the United States. To read the statute in such a fashion, however, would be to attribute to Congress an intention to select for special mention that which was already embraced by the first part of the statute. The history of conspiracy teaches that Congress undoubtedly had something else in mind.

Conspiracy originated in the thirteenth century as a crime punishing conduct equivalent to that now reached by the action for malicious prosecution. ${ }^{24} \mathrm{By}$

23. The coverage of the first clause of the conspiracy statute was at one time held to be limited to conduct proscribed by criminal statutes, on the ground that only an act which could "be prosecuted by criminal proceedings" qualified as an "offense." United States v. Sanche, 7 Fed. 715 (C.C.W.D. Tenn. 1881) ; Pereles v. Weil, 157 Fed. 419, 423 (E.D. Wis. 1907) ; In re Wolf, 27 Fed. 606, 611 (W.D. Ark. 1886) ; United States v. Payne, 22 Fed. 426, 427 (D. Kan. 1884) ; United States v. Watson, 17 Fed. 145, 148 (N.D. Miss. 1883) ; see United States v. Britton, 108 U.S. 199, 206 (1883). "Offense" has since been extended to include any conduct "which by act of Congress is prohibited in the interest of the public policy of the United States, although not of itself made punishable by criminal prosecution but only by suit for penalty." United States v. Hutto, 256 U.S. 524, 529 (1921); see United States v. Wiesner, 216 F.2d 739, 741 (2d Cir. 1954), 43 Geo. L.J. 511 (1955); United States v. Winner, 28 F.2d 295, 298-99 (N.D. I11. 1928), aff'd, 33 F.2d 507 (7th Cir. 1929), 42 Harv. L. Rev. 574, 77 U. PA. L. Rev. 535.

The contention that "offense" includes any conduct prohibited by statute or regulation, even when the prohibition is not "penal" in nature, was rejected in United States v. Brown, 6 F. Supp. 331 (W.D. Ky. 1933). But see United States v. Galleanni, 245 Fed. 977, 978-79 (D. Miass. 1917) (mistakenly relying upon In re Coy, 31 Fed. 794 (C.C.D. Ind. 1887), aff'd, 127 U.S. 731 (188S), which involved a federal statute making it a federal offense to violate certain state laws, for the proposition that "offense" includes common-law offenses) ; Taylor v. United States, 2 F.2d 444, 445 (7th Cir. 1924), cert. denied, 266 U.S. 634 (1925) ; United States v. Komai, 286 Fed. 450 (S.D. Cal. 1923). There are, of course, no common-law offenses against the United States. United States v. Coolidge, 14 U.S. (1 Wheat.) 414 (1816); United States v. Hudson, 11 U.S. (7 Cranch) 31 (1812); cf. United States v. Eaton, 144 U.S. 677, 687 (1892). But see United States v. Galleanni, supra. For a discussion of the meaning of "offense" in varying contexts, see Dugan \& McNamara, Inc. v. United States, 127 F. Supp. 801, 803-04 (Ct. Cl. 1955).

24. Ordinance Concerning Conspirators, 1305, $33 \mathrm{Edw}$. 1. The texts of this statute and others of the same period are set out in Sayre, Crininal Conspiracy, 35 HARv. L. REv. 393, 395-96 (1922). The origin of conspiracy is developed in detail in WINFIELD, THE History of Conspiracy and Abuse of Legal Procedure (1921), reviewed in Holdsworth, Book Review, 37 L.Q. Rev. 462 (1921) ; Harrison, Conspiracy as a Crimse and as a Tort IN ENGLISH LAW 3-13 (1924).

For general historical treatments of conspiracy, see Sayre, supra; HARRISON, op. cit. supra; Bryan, The Developarent of the English Law of Conspiracy (1909); Wright, Criminal Conspiractes and Agreements (1887) (containing a section by Carson on the American cases); Eaton, Conspiracy to Commit Acts Not Criminal Per Se, 6 Colum. L. Rev. 215 (1906) ; 2 Bishop, Criminal Law 120-200 (9th ed. 1923). Brief discussions may be found in Harno, Intent in Crinninal Conspiracy, 89 U. PA. L. Rev. 624 (1941); Arens, supra note 9, at 243-46; 2 Stephen, History of Criminal LAw of ENGLand 227-29 (1883); Falter v. United States, 23 F.2d 420, 423 (2d Cir. 1928). 
the early seventeenth century, under the aegis of Star Chamber, it had become a generalized inchoate crime encompassing the malicious agreement alone, even if its object had not been attained. ${ }^{25}$ Less than a century later, the judges of the King's Bench had extended the conspiracy concept to make criminal all agreements which had crimes as their objects. ${ }^{26}$ And by the early eighteenth century, conspiracy came to be used as a means of punishing "all confederacies whatsoever, wrongfully to prejudice a third person." ${ }^{27}$ The ease with which so vaguely defined a crime could be used to punish persons agreeing to do that which would not be criminal, even if accomplished by an individual, led to attempts to narrow it. The result was Lord Denman's now famous definition of conspiracy as an agreement "to do an unlawful act, or a lawful act by unlawful means."28 But "unlawful" proved little better as a guide than the formulation preceding it. To the extent that "unlawful act or ... means" were not defined as conduct independently made criminal by statute, these words left to the judges a tremendous range of crime-creating power. ${ }^{29}$ And that power was enthusiastically exercised. The law of conspiracy became an economic and political weapon, used against a rising labor movement and against groups threatening the status quo in many other areas of society..$^{30}$

25. Poulterer's Case, 9 Co. Rep. 55b, 77 Eng. Rep. 813 (K.B. 1611); see HARRISoN, op. cit. supra note 24 , at 16 ; other authorities cited note 24 supra. There are some states which still retain the requirement that the object of the conspiracy must be a crime if committed by an individual, though this has usually been accomplished by statute rather than by case law. E.g., Wrs. STat. $\$ 939.31$ (1955); see Note, The Objects of Criminal Conspiracy-Inadequacies of State Law, 68 HARv. L. Rev. 1056, 1058, 1065 (1955).

26. See the discussion of cases in Wright, op. cit. supra note 24, at 26; HARRISon, op. cit. supra note 24 , at 16-17, 21-22.

27. 1 Hawkins, Pleas of The CRown 348 (6th ed. 1787). Sayre sees Hawkins's statement as illustrative of the moralizing current in seventeenth-century decisions and points to Lord Mansfield's classic remark (though uttered a century later) as typical of this attitude: "Whatever is contra bonos nores et decorum, the principles of our law prohibit, and the King's Court, as the general censor and guardian of the public manners, is bound to restrain and punish." Jones v. Randall, Lofft 383, 385, 98 Eng. Rep. 706, 707 (K.B. 1774), quoted in Sayre, supra note 24, at 401. See HARRISON, op. cit. supra note 24, at 23-32.

28. The King v. Jones, 4 B. \& Ad. 344, 110 Eng. Rep. 485,487 (K.B. 1832) ; Commonwealth v. Hunt, 45 Mass. 111, 123 (1842), cited in Pettibone v. United States, 148 U.S. 197,203 (1893).

29. See, e.g., State v. Kemp, 126 Conn. 60, 77-78, 9 A.2d 63, 71-72 (1939) ; Commonwealth v. Donoghue, 250 Ky. 343, 349-50, 63 S.W.2d 3, 5-6 (1933), 43 Y ALE L.J. 659 (1934), 11 N.Y.U.L.Q. 469 (1934) ; State v. Buchanan, 5 H. \& J. 317, 351-52 (Md. 1821). See also Prevezer, Conspiracy and Public Mischief, 17 MODERN L. Rev. 72 (1954); Note, 68 HAsv. L. REv. 1056, 1059 (1955); authorities cited note 24 supra.

30. See 8 Holdsworth, A History of English Law, 381-84 (2d ed. 1937) ; Bryan, op. cit. supra note 24, ch. 5; Arens, Conspiracy Revisited, 3 Bufralo L. Rev. 242, 259-6S (1954) ; Nelles, The First American Labor Case, 41 YALE L.J. 165, 193-200 (1931); Sayre, Labor and the Courts, 39 Y $\mathrm{ALE}$ L.J. 682, 684-87 (1930) ; Sayre, Criminal Conspiracy, 35 HaRv. L. Rev. 393, 413-16 (1922) ; Holdsworth, Conspiracy and Abuse of Legal Process, 37 L.Q. Rev. 462, 465-66 (1921); Digby, The Law of Criminal Conspiracy in England and Ireland, 6 L.Q. REv. 129, 134-43 (1890). In civil-law countries, conspiracy appears to have more pronounced political connotations than it does in common-law countries. See Wagner, Conspiracy in Ciznil Law Countries, 42 J. CRIM. L., C. \& P.S. 171, 182 (1951). 
By the middle of the nineteenth century, enough cases had been decided to permit classification of conspiracy in terms of the kinds of objects which made criminal agreements to attain them. In addition to the substantive crimes, at least a half-dozen recognized objects had crystallized which were not criminal in an individual. ${ }^{31}$ Among these, fraud was probably the best known. ${ }^{32}$

It was at this stage in the development of conspiracy law that the federal conspiracy statute was enacted. Congressional limitation of the classes of unlawful objects under that statute to two-"offense" and "defraud"-would seem, therefore, to have signified an intention to discard all but fraud from among the noncriminal objects and thereby to make somewhat more precise a concept which had already been plagued by entirely too much expansibility.

A detailed examination of the cases dealing with "defraud the United States" will reveal that the effort did not prove successful. The phrase has had no fixed meaning. Instead, it has acquired a series of meanings-some supplanting prior ones, others existing concurrently.

\section{The Legislative Setting}

The end of the Civil War brought with it insistent demands for relief from the tax burden which Congress had imposed on what was still an immature economy. But the need for large revenues persisted. One obvious means of meeting this need and at the same time giving heed to the resentment was to collect more efficiently that which was already taxable. Since excise taxes on whisky were designed to supply the greatest part of the federal revenue and since payment of these taxes was being evaded regularly, congressional attention turned to the techniques of avoidance then flourishing. Chief among them were bribes to government distillery inspectors, false entries on documents required to be submitted to the Government in connection with excise taxes and false markings on whisky cases. ${ }^{33}$

The first legislative attempt to deal with the problem culminated in a statute aimed at the corruptible government inspectors stationed at the distilleries. In 1866, Congress made it a crime for these inspectors to conspire with distillery proprietors or with anyone else "to defraud the United States of the revenue

31. The most widely recognized categories are set out in HARRISON, op. cit. supra note 24 , at 146-47, as: conspiracy to defraud a private person "by means which would give a civil remedy at law or in equity, though this is by no means certain"; conspiracy to commit an act contrary to public morality; conspiracy to defeat or pervert justice; conspiracy to defraud members of the public generally; and conspiracy to injure a private individual. See also United States v. Gordon, 22 Fed. 250, 251 (D. Minn. 1884) ; State v. Buchanan, 5 H. \& J. 317, 351-52 (Md. 1821); WRIGHT, op. cit. supra note 24, at 23-51; Digby, supra note 30 , at $131-32$.

32. According to Sayre, e.g., "the actual decisions, apart from the frand cases, lend small support to the prevalent conceptions" that "neither the end pursued nor the means used need necessarily be criminal." Sayre, Criminal Conspiracy, 35 HARv. L. Rev. 393, 422 (1922). (Emphasis added.)

33. See references in note 35 infra. 
or tax arising from distilled spirits," or, "with intent to defraud the United States of such revenue or tax," to make "any false or fraudulent entry, certificate or return." 34

Before any opportunity arose to measure the impact of the 1866 statute, the continuing clamor for even greater repression of the tax violator ${ }^{35}$ impelled Congress, in 1867, to pass "An Act to amend existing Laws relating to Internal Revenue and for other Purposes"-a thirty-four-section statute which plugged loop-holes in the tax laws and, in addition, created a number of new tax offenses. ${ }^{36}$ The conspiracy provision, section 30 , was added to the House bill by the Senate. ${ }^{37}$ Not a single explanatory reference to it appears in the entire body of hearings and reports. All that can be said with certainty about section 30 , then, is that it was enacted at a time and in a setting which strongly suggest that it was aimed at conspiracies either to commit offenses against the internal revenue or to defraud the United States of internal revenue. ${ }^{38}$

As might be expected, it was to this legislative setting that counsel looked first for a guide to the statute's meaning. Indeed, both prosecutors and defense

34. Act of July 13,1866 , ch. $184, \S 38,14$ Stat. 159 . See 46 Cong. Globe, 39th Cong., 1st Sess. 2387-88 (1866) (remarks of Senator Thayer).

35. See 1 Reports of Commitrees, 39th Cong., 2d Sess., H. Rep. 15 (Feb. 11, 1867); 3 id., H. Rep. 24 (Feb. 25, 1867) ; 47 Cong. GLoBe, 39th Cong., 2d Sess. 1490-91 (1867); reports of whisky frauds in the following issues of the N.Y. Times: Nov. 18, 1866, p. 5, col. 3; Nov. 20, 1866, p. 8, col. 3; Nov. 21, 1866, p. 8, col. 3 ; Nov. 24, 1866, p. 2, col. 4; Nov. 25, 1866, p. 5, col. 2; Dec. 11, 1866, p. 2, col. 4; Feb. 7, 1867, p. 4, col. 5; Feb. 13, 1867, p. 2, col. 2; Feb. 15, 1867, p. 4, col. 5 ; Feb. 19, 1867, p. 5, col. 3; Feb. 20, 1867, p. 2, col. 1; Feb. 26, 1867, p. 1, col. 7, p. 4, col. 5 ; June 2, 1867, p. 4, col. 2; June 13, 1867, p. 4, col. 3; July 6,1867 , p. 4, col. 3; July 13, 1867, p. 4, col. 2; Aug. 17, 1867, p. 2, col. 6 .

36. Act of March 2, 1867, ch. 169, $\$ 30,14$ Stat. 484. The original statute prohibited conspiracy to "defraud the United States in any manner whatever," and contained a number of other criminal provisions, all of which, unlike the conspiracy section $(\$ 30)$, were on their face concerned with revenue offenses. E.g., $i d$. $\$ \$ 26,28,29,32$. In the 1875 codification, the statute was altered to read: "to defraud the United States in any manner or for any purpose." Rev. Stat. $\$ 5440$ (1875). (Emphasis added.) At the same time, the codifiers moved the statute from its former place among internal revenue measures and included it among general penal provisions. 15 CoLum. L. Rev. 544 (1915). See also the reviser's note on legislative history, following 18 U.S.C. $\$ 371$ (1952).

37. 47 Cong. Grobe, 39th Cong., 2d Sess. 1920 (1867) (then $\$ 29$ of the Senate bill).

38. This position appears to have been taken in United States v. Allen, 24 Fed. Cas. 772 (No. 14432) (C.C.E.D.N.Y. 1868). Although refusing to limit the "universality of its language," the court in United States v. Thompson, 29 Fed. 86, 87 (C.C.D. Ore. 1886), conceded that "the manifest purpose of the act was to prevent and punish frauds on the revenue." Similarly, in United States v. Stone, 135 Fed. 392, 398 (D.N.J. 1905), the court intimated that the statute, "in its original form," may "not [have been] applicable to any frauds except those concerning the internal revenue." But it found in the "1878" [sic] revision of the criminal code a clear intention to extend the statute to "every conspiracy to defraud the United States." For the revision transferred the conspiracy statute "from its place in the internal revenue law to a place in the law concerning crimes, and to the subdivision of crimes entitled "Crimes against the Operations of the Government." Furthermore, it substituted for "defraud the United States in any manner whatever" the phrase "defraud the United in any manner or for any purpose." (Emphasis added.) 
counsel, in different contexts, argued that the 1867 statute was aimed only at conspiracy to defraud the United States of internal revenue. But each side had its own special reasons. Prosecutors wished to avail themselves of the longer statute of limitations then applicable to crimes involving the revenue. Defense counsel, on the other hand, were striving for a device by which to restrict section 30's reach, and thought that they had succeeded by reading the conspiracy statute as applicable only to the conduct prohibited in the remaining thirty-three sections of the 1867 revenue measure. The early cases held with the prosecution that section 30 set forth a revenue offense for statute-of-limitations purposes. ${ }^{39}$ But the courts were unwilling to hold it exclusively a revenue measure when such a construction would have allowed a fraud directed at a nonrevenue function of government to escape the statute. ${ }^{40}$

Debate over the new conspiracy law was ended by the Supreme Court's decision in United States $v$. Hirsch. ${ }^{41}$ It accepted the contention that the longer statute of limitations for revenue offenses was not available under section 30. The reason, said Mr. Justice Miller, was that the conspiracy provision's failure to refer to internal revenue, in contradistinction to the existence of a specific reference in each of the other thirty-three sections of the bill, evidenced a congressional intent to make the conspiracy provision generally applicable to the whole body of federal law. Confirmation for this view was found in the bill's title, which described the act as one relating to "internal revenue and for other purposes." The conspiracy section was equated with "other purposes" and the phrase was interpreted broadly-though "other purposes" could reasonably have been taken to mean no more than that the statute not only levied new taxes but also created new tax crimes.

Yet another reason underlay the Court's position in Hirsch. Hirsch et al. had been indicted for a conspiracy to defraud the United States of duties on imports, taxes which fell outside the internal revenue category. Rational application of the prosecutor's argument would have required the court to read the legislative history into the statute for purposes both of the statute-of-limitations issue and of determining the section's coverage. The longer statute of limitations would have been applicable, but at the expense of eliminating frauds on external revenue from the scope of the conspiracy statute. In refusing to accept a distinction which may have been historically sound but appeared to be operationally undesirable, the Court, in reversing Hirsch's conviction, gave to the Government far more than it took away. Though conspiracy prosecutions would henceforth be bound by a shorter statute of limitations, prosecutors,

39. United States v. Dennee, 25 Fed. Cas. $\$ 18,820$ (No. 14948) (C.C.D. La. 1877); United States v. Fehrenback, 25 Fed. Cas. 1057, 1058 (No. 15083) (C.C.D. La. 1875). 1877).

40. E.g., United States v. Stevens, 27 Fed. Cas. 1312, 1314 (No. 16392) (C.C.D. Me.

41. 100 U.S. 33 (1879). The holding of the Court was by no means unexpected. The "bent of Judge Miller's mind [was] toward upholding the authority of the federal government." Fairatan, Mr. Justice Miller and the Supreme Court 309 (1939). 
unconfined by legislative history, would be able to press for new applications of the statute. "The conspiracy here described," said Justice Miller, "is a conspiracy to commit any offence against the United States. The fraud mentioned is any fraud against them. It may be against the coin, or consist in cheating the government of its land or other property."42

\section{From "Legal" Fraud to "Equitable" Fraud}

If the impact of Hirsch had extended no further than the holding itself, conspiracy to defraud the United States would have remained a conventional crime, reaching the inchoate stage of what had been classed either as a cheat or as "legal" fraud at common law. ${ }^{43}$ Following the common-law concept, its core would have been the jointly planned statement designed to induce the Government, acting in reliance on the falsehood, to part with money or property. But Justice Miller's rhetorical flourish-that the statute reached "any fraud" against the United States-apparently suggested to prosecutors that this statute might be less limited than its restrictive common-law terms indicated. Taking their inspiration from the tone of Hirsch and their license from the statutory language, which prohibited conspiracy to defraud the United States "in any manner or for any purpose," they began a long-term process of pouring new content into conventional forms, with each new theory coexisting alongside the old.

The pressure upon the prosecutors to follow this course ought not to be minimized. The last quarter of the nineteenth century had witnessed an unprecedented expansion of the United States and of national governmental authority. It soon became apparent that rudimentary criminal codes, conceived

42. 100 U.S. at 35. See also United States v. Owen, 32 Fed. 534,536 (D. Ore. 1887); United States v. Whalan, 28 Fed. Cas. 531 (No. 16669) (D. Mass. 1868) (dictum).

43. Cheats as common law crimes are described in HAlL, TheFT, LAw AND SocIETY 10 (1935). In the seventeenth century, a cheat was defined as "the fraudulent obtaining the property of another, by any deceitful or illegal practice or token ... which affects or may affect the public." Ibid. If conspiracy to cheat was involved, effect on the public was not a necessary element of the offense. See HarRIson, op. cit. supra note 24, at 82-83. "Legal" fraud represented the importation of the conventional common-law concept of fraud into the criminal law. HALL, op. cit. supra at 15-16, 19-22.

Though many refinements have appeared over the years, the basic outlines of fraud have remained the same. An actionable fraud requires (1) a material false representation, which is (2) known by the maker to be false, and is (3) made with the purpose of inviting another's reliance, and upon which (4) the other, believing it to be true, does in fact detrimentally rely, (5) his damages being proximately caused by such reliance. Bishop v. E. A. Strout Realty Agency, 182 F.2d 503, 505 (4th Cir. 1950); Equitable Life Ins. Co. v. Halsey, Stuart \& Co., 112 F.2d 302, 308 (7th Cir. 1940), rev'd on other grom 312 U.S. 410, 420 (1941) ; Boatman's Nat'1 Co. v. M. W. Elkins \& Co., 63 F.2d 214, 216 (8th Cir. 1933). See also Wriget, op. cit. supra note 24, at 27-8. This "deceit" core of fraud is to be found also in many suits seeking equitable relief for fraud. Southern Development Co. v. Silva, 125 U.S. 247, 249-50 (1888) ; Butler v. Watkins, 80 U.S. (13 Wall.) 456, 464 (1871); McNabb v. Thomas, 190 F.2d 608, 609 (D.C. Cir. 1951). Equitable fraud is, of course, much broader. See notes 56-61 infra and accompanying text. 
for rural societies and confined by state lines and local considerations, could not cope with those who saw manifold opportunities for gain in the new activities of the federal government. ${ }^{44}$ The judges joined in responding to these pressures, perhaps because they recognized the difficulties facing a Congress inexperienced in dealing with so broad a range of problems. The statute was early loosed from any mooring it might have had in the substantive crimes. ${ }^{45}$ Courts proclaimed instead that the statute was "very sweeping" in its terms ${ }^{46}$ and was aimed at all frauds which "human ingenuity can devise."47 It was said to have "a more comprehensive meaning" than at common law and to reach every species of fraud, regardless of "whether [it] . . . had been declared a crime by any statute or not." 48

Just what was meant by these broad statements is not clear, for the cases in which they appeared were no different from Hirsch. All involved conspiracies to make false statements to government officers, with the intention of inducing action by such officers. And the action, if taken, would in every instance have deprived the federal government of its money or property. For the most part, the cases arose from the presentation of false affidavits to the land office in support of applications for land under the homestead laws. ${ }^{49}$ Yet none of the opinions dealt expressly with the reasons why these prosecutions were not brought under the "offense" portion of the conspiracy statute. The most obvious explanation is that there were few statutes specifying offenses in this area. And those that existed were, in general, narrowly construed. For example, a "false writing" statute had been enacted in 1823 under which some of the early cases might have been prosecuted, but the statute looked very

44. See Harno, Some Significant Developments in Criminal Law and Procedure in the Last Century, 42 J. CRIM. L., C \& P.S. 427, 456-60 (1951); Conboy, Federal Criminal Laze, in Law: A CENTURy of Progress 295, 300-01 (1937).

45. United States v. Sacia, 2 Fed. 754, 755 (D.N.J. 1880).

46. Ibid.

47. United States v. Whalan, 2S Fed. Cas. 531, 531-32 (No. 16669) (D. Mass. 1868); cf. United States v. Cohn, 270 U.S. 339, 346 (1926).

48. United States v. Whalan, supra note 47, at 532; accord, United States v. Stone, 135 Fed. 392, 398 (D.N.J. 1905); United States v. Gorden, 22 Fed. 250, 251 (D. Minn. 1884). But see United States v. Walsh, 28 Fed. Cas. 394, 396 (No. 16636) (C.C.E.D. Mo. 1878 ) (intimating that the object of the conspiracy must itself be a crime).

49. See Hyde v. United States, 225 U.S. 347 (1912); United States v. Barber, 219 U.S. 72 (1911) ; United States v. Biggs, 211 U.S. 507 (1909) ; Dealy v. United States, 152 U.S. 539 (1894) ; Chaplin v. United States, 193 Fed. 879 (9th Cir.), cert. denied, 225 U.S. 705 (1912); United States v. Wells, 192 Fed. 870 (2d Cir.), cert. denied, 225 U.S. 714 (1912) ; Richards v. United States, 175 Fed. 911 (8th Cir. 1909), cert. denied, 218 U.S. 670 (1910) ; United States v. Raley, 173 Fed. 159 (D. Ore. 1909); Jones v. United States, 162 Fed. 417 (9th Cir.), cert. denied, 212 U.S. 576 (1908); United States v. Black, 160 Fed. 431 (7th Cir. 1908) ; Ware v. United States, 154 Fed. 577 (8th Cir.), cert. denied, 207 U.S. 588 (1907); United States v. Doughten, 186 Fed. 226 (C.C.E.D. Wash. 1911); United States v. Robbins, 157 Fed. 999 (D. Utah 1907) ; United States v. Burkett, 150 Fed. 208 (D. Kan. 1907); United States v. Brace, 149 Fed. 874 (N.D. Cal. 1907); United States v. Peuschel, 116 Fed. 642 (S.D. Cal. 1902) ; United States v. Owen, 32 Fed. 534 (D. Ore. 1887). 
much as if it were limited to false claims for money. ${ }^{50}$ Another statute, in 1863, did little to broaden it. ${ }^{51}$ Until fairly recent date, there was no false statement statute of general applicability. ${ }^{52}$ In this case, as in others, "conspiracy to defraud the United States" was called to serve instead.

Courts continued to deal primarily with legal fraud situations, but the pressure of prosecutions succeeded before very long in transforming the judges' broad rhetorical flourishes into holdings. The emphasis in the cases turned from some specific economic deprivation (to be suffered by the United States in a proprietary sense) as a necessary object of the conspiracy ${ }^{53}$ to the means used to attain the object. Not only was it unnecessary that conspirators succeed in depriving the Government of money or property, ${ }^{54}$ but it soon became unnecessary that those involved in an "agreement" actually intend to deprive the United States of any identifiable money or property. If falsehood had been made to take the place of facts in connection with a lawful function of government, then enough "fraud" existed to qualify as the unlawful object of a conspiracy. ${ }^{55}$

This transition from concern with the end of fraudulent conduct to emphasis upon the planned falsehood itself came at the start of the twentieth century and marked the beginning of a fundamental reorientation. In Tyner v. United

50. Act of March 3,1823, ch. 38, 3 Stat. 771 ("an Act for the punishment of frauds committed on the government of the United States").

51. Rev. Stat. \$ 5438 (1875).

52. 18 U.S.C. $\$ 1001$ (1952) did not take its present form until 1934. See the discussion in United States v. Gilliland, 312 U.S. 86, 91-93 (1941). The federal perjury statute, 18 U.S.C. $\S 1621$ (1952), has, of course, been in the books much longer-since 1790. Annotations to REv. STAT. $\$ 5392$ (1875). The perjury provision, however, is more limited in nature than the present $\S 1001$ and has always been characterized by stricter requirements of proof than are demanded of most criminal statutes. See, e.g., Weiler v. United States, 323 U.S. 606 (1945).

53. E.g., United States v. Thompson, 29 Fed. 86 (C.C. Ore. 1886), held that conspiracy to defraud the United States was not involved in a joint scheme to use false statements in order to obtain a privilege of occupying government land. Though marketable, the privilege would not ripen into actual title to the land unless the squatter continued to develop it for eight years and satisfied other conditions. The court argued that the fraud part of the conspiracy statute required not only a false statement, but, in addition, one which, if relied upon, would have deprived the United States of its proprietary interest in the land. Here, since the conditions which would have to be met before the Government would surrender title might never occur, "deprivation" was too remote. Though Congress might provide sanctions for misrepresentation under the act, and though a prosecution for perjury could be brought for the false statements made under oath, the court did not feel that the scheme was reached by the phrase "defraud the United States." See also United States v. Milner, 36 Fed. 890,891 (C.C.N.D. Ala. 1888).

54. See, e.g., United States v. Frisbie, 28 Fed. 808 (C.C.E.D. La. 1886); United States v. Sacia, 2 Fed. 754, 755 (D.N.J. 1880).

55. Some of the early cases marking the transition are Hyde v. Shine, 199 U.S. 62, 82 (1905) ; Palmer v. Colladay, 18 App. D.C. 426,433 (D.C. Cir. 1901); United States v. Lonabaugh, 158 Fed. 314, 315-16 (D. Wyo. 1907), rev'd on other grounds, 179 Fed. 476 (8th Cir. 1910). 
States, "56 the word "defraud" was completely severed from the common law of fraud or cheats. Under the guise of applying a rule of construction "that a statute which is made for the good of the public ought, although it be penal, to receive an equitable construction"-a statement which could as easily be made of any criminal statute-the court announced that the word "defraud" was to be read "in its equitable sense." 57 Quoting from Justice Story, the court described equitable fraud as including "all acts, omissions and concealments which involve a breach of legal or equitable duty, trust, or confidence justly reposed, and are injurious to another, or by which an undue and unconscientious advantage is taken of another."5s Applied to the conspiracy statute, this meant that:

Any wilful or corrupt misconduct on the part of an official of the [post office] department that operates to impair [its] ... administration works a wrong to the United States and does them some substantial injury. The injury may be pecuniary, that is to say, one whereby public money or property may have been taken, destroyed, or expended, but it may also be one the general damage resulting from which may be most serious and far reaching, and yet not of a specific character susceptible of certain ascertainment and pecuniary compensation. ${ }^{59}$

Neither actual injury nor potential injury need be demonstrated as the end result of the conspiracy. The false practices themselves were now to give color and meaning to the word "defraud" and content to the second half of the federal conspiracy statute; injury to the Government would be conclusively presumed.

Unfortunately, in enunciating this doctrine, the court did not attempt to characterize with precision what it meant by "any wilful or corrupt misconduct." This lack of definition might have been expected of a concept fashioned by a court of conscience, whose very function was to create a remedy for those victimized by new ways of wrongdoing. ${ }^{60}$ It was, however, completely out of

\footnotetext{
56. 23 App. D.C. 324 (D.C. Cir. 1904).

57. Id. at 362 .

58. Ibid.

59. Id. at $362-63$.

60. In dealing with fraud, equity was not as interested as the law courts in statements or representations of fact. It was primarily concerned with conduct as a whole. "[T] court of Chancery was particularly fitted to undertake inquiries of this kind, since there was no jury, and ample opportunity to call upon the parties to account for their conduct. Thus 'fraud' came to include a wide range of transactions 'in which the Court is of opinion that it is unconscientious for a person to avail himself of the legal advantage which he has obtained.' ... The primary difficulty about fraud, in the sense in which it was used by Equity in its exclusive jurisdiction, was that it was not capable of precise definition ..." Keeton, Introduction to EQuity 273-74 (4th ed. 1956). See note 134 infra. Compare the incorporation of "equitable fraud" with the mail fraud statute, coupled with the admonition "that the constructive frauds which equity in civil cases sometimes sets up to do justice will not suffice under this criminal statute; . . . there must be a purpose to do wrong which is inconsistent with moral uprightness." Shushan v. United States, 117 F.2d 110, 115 (5th Cir. 1941) ; see Epstein v. United States, 174 F.2d 754, 765-68 (6th Cir. 1949).
} 
tune with one of the principal objectives of the criminal law-affording potential offenders notice, in advance of action, of what is prohibited and what permitted. Such imprecision necessarily allowed the prosecutor more easily than in the past to reach conduct which, in his view, threatened governmental authority. It thus introduced under the cloak of words of seemingly settled meaning an evolutionary conception of the law of crime clearly at odds with the old saws that federal crime is closely defined by the legislature and that there are no judge-made "common law offenses against the United States."01

\section{Interference With Government as the Unlawful Object}

Curley v. United States ${ }^{62}$ followed close upon Tyner and crystallized a view which had only been implicit there. The facts were simple ones. James Michael Curley, not yet mayor of Boston, had agreed to take a civil service examination in behalf of an applicant for a position in the federal civil service. This could easily have been classed as a conspiracy falsely to represent Curley as the applicant, the ultimate object being to induce the Government to pay an employee it had never contracted to hire. It was fraud in the inducement and would probably have qualified for the "legal" fraud category. But Judge Aldrich, for the First Circuit, was not content to rest his holding on so narrow a ground. After conceding that "defraud" did have an "ordinary" meaning which encompassed only "frauds relating to money and property," 33 he concluded that the common-law meaning must yield when the statutory context connoted a broader sense. Such a connotation he found precisely where the Tymer court had found it. Conspiracy to defraud the Government was to be read more broadly than conspiracy to defraud a private person. Neither legislative nor general historical support was cited; morality served instead to legitimize the departure from the "ordinary" meaning. "As a moral offense," the court said, "defrauding the government of its right and its facilities for rendering a proper service to the people. . . cuts deeper than defrauding the government of a wheelbarrow, and it is unquestionably within the power of the government to protect itself against that kind of a fraud." 64 The existence of power in Congress to convert moral judgments into legal ones thus appears to have been confused with the manner in which that power had in fact been exercised. And the vehicle, once more, was the phrase "defraud the United States," which was now read as employing "the most general terms and the broadest possible phraseology" to reach conspiracy to defraud the United States of the right to render proper service to the people. ${ }^{65}$ infra.

61. See Coolidge, Hudson and Eaton cases, cited note 23 supra; notes 127, 136

62. 130 Fed. 1 (1st Cir.), cert. denied, 195 U.S. 628 (1904).

63. Id. at 6-7.

64. Id. at 9.

65. Id. at 9-10. To the same effect, see United States v. Bradford, 148 Fed. 413, 421-22 (C.C.E.D. La. 1905), aff'd, 152 Fed. 616 (5th Cir.), cert. denied, 206 U.S. 563 (1907):

It is certainly just as important that the government should not be defrauded with regard to its operations, even if no pecuniary value is involved, as that it 
Even after Tyner and Curley, however, an important limitation on the meaning of "defraud the United States" remained. The crime still required some fairly direct, almost physical, relationship between the defrauder and the Government he sought to defraud. Two developments combined to chip away at this requirement.

The first grew out of United States $v$. Robbins, in which the court announced that, to be guilty of conspiracy to defraud the United States, one need not have made or even have planned to make an affirmative misstatement. ${ }^{66} \mathrm{It}$ was enough if the defendants failed to disclose that which they should have disclosed. Silence under such circumstances was said to constitute as affirmative a misrepresentation as a spoken lie. This doctrine simply extended to the criminal law the refined analysis of fraud then making its appearance in civil law to meet the needs of a society in which caveat emptor had proved inadequate. ${ }^{67}$ But the Robbins extension came at a time when the "should have disclosed" portion of the formula had become particularly cloudy. Predicating liability upon failure to disclose information, as in criminal omissions generally, depends upon the existence of a standard which measures the obligation of disclosure. When a statute imposes such an obligation upon a defined class of persons, failure to disclose poses no greater problem than affirmatively wrongful disclosure. The statute supplies the objective factor which can be measured and evaluated, just as the affirmative statement does in cases of criminal commission. But when no statute fixes the measure of obligation and it must be drawn from the case law, neither judge nor jury has a finite, measurable concept which can be held up to view, its meaning ascertained and its impact measured. Instead, the standard of disclosure becomes one of shifting content, dependent for its meaning upon a subjective estimate-after the fact and case by case-of the effect of nondisclosure upon the end sought to be served by the statute creating the crime.

The second and more troublesome development came from the change in the end which was to be served by the objectionable conduct. Instead of the originally necessary intent to deprive the Government of money or property, it now sufficed, under Curley, if the Government's ability to render "proper service" to the people was likely to be impaired. It was but a short step to describ-

should not be defrauded of its property. In fact, I believe that it is far more important that the government should be protected against the former class of frauds, and it would be astonishing, indeed, if Congress had failed to afford protection against such frauds.

66. 157 Fed. 999, 1000-02 (D. Utah 1907). Once again, the facts did not require the language used by the court. The defendants had utilized straw men to purchase from the United States more land than they could lawfully have purchased in their own names. The purchase price had been furnished by the defendants, with the straws holding the land in secret trust for them. Fairly clearly, this could have been treated as a case of affirmative false representation to induce the sale of land by the Government to persons who would otherwise never have gotten the land.

67. See Radin, The Lawful Pursuit of Gain $48-55$ (1931); Hali, Theft, Law AND SOCIETY 32-33 (1935). 
ing the prerequisite "purpose" as an intention to cause any "lessening [of] the power of the federal government ... to maintain [its departments] in [an] efficient condition ...." So vaguely defined an end did little to make clear the extent to which persons dealing with Government, or even those not dealing with it, owed an obligation to disclose information which would enable it to operate "efficiently."

In Haas v. Henkel, ${ }^{69}$ a case whose facts would not easily fit within the "legal" fraud category, the Supreme Court placed its imprimatur upon the most extreme extension of the statute. Holmes, an Agriculture Department statistician, had agreed to disclose to an outsider, Haas, information made confidential by departmental regulation and custom. The information was to be used by Haas to gain advantage in speculating in grain futures. Neither Haas nor Holmes had made a false representation to a government official to induce action by that official. The fraud was rather an implicit one, consisting in Haas's participation in Holmes's failure to live up to the implied warranty of all jobholding: that honest and faithful service will be rendered by employee to employer. This breach of the obligation of confidentiality imposed by regulation and usage was the sort of misconduct for which disciplinary action could have been taken. Nevertheless, a strained extension of the word "defraud" was used to bring the conduct within the conspiracy statute. The Supreme Court said:

The statute is broad enough in its terms to include any conspiracy for the purpose of impairing, obstructing or defeating the lawful function of any department of Government. . .. [A] ny conspiracy which is calculated to obstruct or impair [the Agriculture Department's] ... e efficiency and destroy the value of its operations and reports as fair, impartial and reasonably accurate, would be to defraud the United States by depriving it of its lawful right and duty of promulgating or diffusing the information

68. United States v. Morse, 161 Fed. 429, 435-36 (C.C.S.D.N.Y. 1908), aff'd, 174 Fed. 539 (2d Cir. 1909); see United States v. Walter, 263 U.S. 15, 18 (1923) ; United States v. Lonabaugh, 158 Fed. 314, 316 (D. Wyo. 1907), rev'd on other grounds, 179 Fed. 476 (8th Cir. 1910), discussed in Conspiracy in Fraudulent Entries on Goveriment Land, 71 Cent. L.J. 219 (1910).

69. 216 U.S. 462, 476-81 (1910). The lower court opinion in Haas is reported at 166 Fed. 621, 626-27 (C.C.S.D.N.Y. 1909). The case arose on removal proceedings which had been instituted so that the defendants, who had been indicted in both the Southern District of New York and the District of Columbia, could be tried first in the District of Columbia. Motions were made to quash the removal proceeding on the ground, inter alia, that the District of Columbia indictments did not charge any offense against the United States. 216 U.S. at 471,476 . Some of the counts involved conspiracy to commit an offense-the bribing of Holmes to supply advance information on cotton crop reports or to falsify some of them. Other counts charged conspiracy to defraud the United States "by secretly obtaining information from Holmes which he should acquire in his official character as Associate Statistician and should, in violation of his official duty, give out secretly to his co-conspirators . .. in advance of the time when these reports were to be promulgated according to law." $I d$. at 477-79. The text discussion is concerned with this latter charge. 
so officially acquired in the way and at the time required by law or departmental regulations. ${ }^{70}$

This decision marked the end of any attempt to restore to the word "defraud" its "ordinary" meaning. Defense counsel now began a search for an ascertainable standard of obligation owed by all persons to their government, for all could agree that there would be no conspiracy to defraud the United States if defendants had agreed to do only "that which the law allowed."71 But what the law allowed was of course the very question impossible of accurate determination under a statute making it a crime to agree to interfere with the efficient operation of government. Which law was to be looked to? The federal criminal code? The federal statute law? Federal common law? Regulations of government departments? State law? The questions raised by Haas $v$. Henkel were many. Unfortunately, most of them had already been answered, and in contexts in which the pressure was toward expanding "defraud" beyond its "ordinary" meaning. It was too much to expect that the pronouncements of another day would be carefully sifted and restricted to the fact situations they originally reflected. Thus, what the law "allowed" was not simply conduct not specifically outlawed by the federal criminal code. Nor was it, as already seen, all conduct not denominated a cheat or a fraud at common law. ${ }^{72}$ Indeed, to the extent that "unlawful" conduct had been assimilated to the civil law of fraud, it had come to embrace both legal and equitable conceptions. ${ }^{73}$ In addition, regulations and customs as well as statutes furnished standards of duty and obligation. ${ }^{74}$ Perhaps the outstanding characteristic

70. Id. at 479-80; accord, Crawford v. United States, 30 App. D.C. 1, 12 (D.C. Cir. 1907), rev'd on other groutnds, 212 U.S. 183 (1909) ("[A]ny agreement the object of which is to deprive the government of the services of those who are intrusted with the discharge of duties which are essential to its proper administration is a conspiracy to defraud."); Outlaw v. United States, 81 F.2d 805, 807 (5th Cir. 1936) ; United States v. Tynan, 6 F.2d 668, 669 (S.D.N.Y. 1923). But see 166 Fed. 621, 626 (C.C.S.D.N.Y. 1909) (view of Judge Ward, below, in Haas).

The resemblance of the language in Haas to that of the conspiracy provision of the Alien and Sedition Act of 1798 is marked. The latter read: "[I]f any persons shall unlawfully combine or conspire together, with intent to oppose any measure or measures of the government of the United States, which are or shall be directed by proper authority, or to impede the operation of any law of the United States [they] ... shall be punished . .." 1 Stat. 596 (1798), reprinted in SMITH, FREEDom's FetTERS 441 (1956). (Emphasis added.)

71. United States v. Biggs, 211 U.S. 507, 521-22 (1909); Fain v. United States, 209 Fed. 525, 531 (8th Cir. 1913) ; United States v. Atlanta Journal Co., 185 Fed. 656, 662 (C.C.N.D. Ga. 1911) ; see Metropolitan Life Ins. Co. v. Baker, 107 F. Supp. 1, 3 (N.D. Tex. 1952), rev'd on other grounds sub nont. Kemp v. Metropolitan Life Ins. Co., 205 F.2d 857 (5th Cir. 1953) ; Prudential Ins. Co. v. Bohlken, 40 F. Supp. 494 (W.D. Mo. 1941).

72. See authorities cited note 43 supra. See also United States v. Raley, 173 Fed. 159, 162 (D. Ore. 1909).

73. See text accompanying notes 56-61 supra; United States v. Keitel, 211 U.S. 370, 393-94 (1908) ; Falter v. United States, 23 F.2d 420, 423 (2d Cir. 1928).

74. See Haas v. Henkel, 216 U.S. 462, 480-81 (1910) ; Tyner v. United States, 23 App. D.C. 324, 355 (D.C. Cir. 1904) ; cf. United States v. Birdsell, 233 U.S. 223, 230-31 (1914). 
of the phrase "defraud the United States" after Haas $v$. Henkel was that, no matter how specifically one sought to define it, it was necessary to leave the definition as open-ended as the functions of government in an expanding society.

\section{New Attempts at Limitation}

The sweeping language of Haas $v$. Henkel invited prosecutors to convert dicta into decision. Whenever misconduct in some way directed at the Government fell short of a specific offense category but seemed nevertheless deserving of punishment, or wherever problems of proof made invocation of the offense portion of the statute questionable, the resourceful prosecutor could turn to this crime of many meanings and of seemingly infinite elasticity.

The first doubts about the implications of Haas made their appearance in United States $v$. Gradwell. ${ }^{75}$ In refusing to class a conspiracy to bribe voters at a congressional election as a conspiracy to defraud the United States, the Supreme Count suddenly discovered the restrictive doctrines it had previously ignored:

[I]t would be a strained and unreasonable construction to apply to such elections this $\S 37$, originally a law for the protection of the revenue and for fifty years confined in its application to "Offenses against the Operations of the Government" as distinguished from the processes by which men are selected to conduct such operations.

When to all this we add that there are no common-law offenses against the United States . . . , that before a man can be punished as a criminal under the federal law his case must be "plainly and unmistakably" within the provisions of some statute, ... and that Congress has always under its control-the means of defeating frauds in the election of its members by enacting appropriate legislation and by resort to the constitutional grant of power to judge of the elections, returns and qualifications of its own members, we can not doubt that the District Court was right in holding that the section was never intended to apply to elections, and that to bribe voters to vote at such an election is not such a fraud upon the United States or upon candidates or the laws of Rhode Island as falls within either the terms or purposes of the section. ${ }^{76}$

Though the current implicit in Gradwell carried a subsequent decision - which refused to class an agreement to interfere with military post exchanges as a conspiracy to defraud the United States ${ }^{77}$-it was dissipated shortly afterwards. In United States $v$. Slater, ${ }^{78}$ defendants

75. 243 U.S. 476 (1917).

76. Id. at 485. A contrary decision had been reached by at least one lower court. United States v. Aczel, 219 Fed. 917, 938 (D. Ind. 1915) (relying upon Haas).

77. Keane v. United States, 272 Fed. 577 (4th Cir. 1921). The "proprietary" nature of the activity was probably determinative of the result. The court emphasized that the Secretary of the Army would be creating crimes through the device of issuing departmental regulations which, unless complied with, could lead to a prosecution for conspiracy to defraud the United States; and that violation of administrative regulations could not be made a crime unless Congress had made it so in advance and prescribed the penalty.

78. 278 Fed. 266 (E.D. Pa. 1922). 
had purchased whisky, an act not itself made a crime by the National Prohibition Act. They were nevertheless prosecuted for conspiracy to defraud the United States and their demurrers overruled, on the theory that the statute was "broad enough to include any act which interferes with or hampers the United States in the successful prosecution of any policy established by law."79

The expansive reading of the statute in Haas and the restrictive construction in Gradwell finally led the Supreme Court to attempt a systematic examination of what the judiciary had wrought. Hammerschmidt v. United States ${ }^{80}$ furnished the occasion. Defendants had been indicted for conspiring to defraud the United States by interfering with the military draft in World War I. Their method of interference was exhortation by pamphlet and speech against war and conscription. Two lower courts held that such activity was "interference" with a "lawful function" of government within the meaning of Haas v. Henkel. A dissenting opinion, however, read the prior cases, or at least those which were felt to be authoritative or persuasive, as requiring the existence of an agreement involving either: "(1) any deception or misleading or (2) any deprivation of a property right. Usually both are found, but it would seem that one there must be, else the accepted definition fails." 81 In order to fit Haas $v$. Henkel within this classification, the dissent found that the defendant in that case had made an "implied promise" to the Department of Agriculture to keep secret the statistics in question. Disclosure of the statistics thus became a breach of the promise and the surreptitiousness which attended it the "artifice" and "concealment of the truth" seemingly necessary to qualify the breach as a fraud. 82

The Supreme Court accepted the dissent and upset the defendants' conviction. Chief Justice Taft, for the Court, sought to restrict Haas to its facts. That case, he said, did not consider

whether deceit or trickery was essential to satisfy the defrauding required under the statute. The facts in the case were such that that question was not presented. The deceit of the public, the trickery in the advance publication secured by bribery of an official, and the falsification of the reports [the latter two of which were involved in other counts], made the fraud and deceit so clear as the gist of the offenses actually charged that their presence was not in dispute. The sole question was whether the fraud there practiced must have inflicted upon the Government pecuniary loss, or whether its purpose and effect to defeat a lawful function of the Government and injure others thereby was enough. ${ }^{83}$

79. Id. at 269. See Head v. Hunter, 141 F.2d 449, 451 (10th Cir. 1944); United States v. Goldsmith, 68 F.2d 5, 7 (2d Cir. 1933), cert. denied, 291 U.S. 681 (1934) (under then 18 U.S.C. $\S 72$, any possibility of prejudice to the United States in collecting taxes due was sufficient impairment of governmental function to qualify false writing as having the purpose of defrauding the United States).

80. 265 U.S. 182 (1924), reversing 287 Fed. 817 (6th Cir. 1923).

81. Hammerschmidt v. United States, 287 Fed. 817, 825 (6th Cir. 1923) (dissenting opinion of Dennison, J.).

82. Id. at 826-27.

83. 265 U.S. at 187. 
Chief Justice Taft went on to give his own definition of the statutory language:

To conspire to defraud the United States means primarily to cheat the Government out of property or money, but it also means to interfere with or obstruct one of its lawful govermental functions by deceit, craft or trickery, or at least by means that are dishonest. It is not necessary that the Government shall be subjected to property or pecuniary loss by the fraud, but only that its legitimate official action and purpose shall be defeated by misrepresentation, chicane or the overreaching of those charged with carrying out the governmental intention. ${ }^{84}$

The Hammerschmidt defendants' "mere open defiance of the governmental purpose to enforce a law by urging persons subject to it to disobey it" was not drawn within the reach of the statute. ${ }^{85}$ No reliance appears to have been placed on the first amendment implications of the case..$^{86}$

If "open defiance" of a governmental course of action was not reached by the statute but "deceit, craft, trickery, or . . . dishonest" means were, then it was at least clear that clandestineness or secrecy was one of the essential elements of the crime. Falsehood, broadly defined, was another, for it is common to deceit, craft and trickery. ${ }^{87}$ But what was meant by "dishonest" means and by "overreaching," each of which, when used against the Government, were said to bring fraud into the picture? Unless the Chief Justice was carried away by his rhetoric and was saying the same thing in seven different ways (which may well prove to be the case), he must have intended to read conspiracy to defraud the United States as embracing more than a conspiracy to make a secretive false statement to a government official or to omit making such a statement when it should have been made.

His use of the phrase "or at least means that are dishonest" would seem to indicate the existence of a class of unlawful means greater in scope than one composed of a combination of the three dishonest means which were specifically set out. In any event, "interference with a lawful function of government" had at least to be by "dishonest" means. ${ }^{88}$ The question which remained was whether "dishonesty" brought with it a more explicit meaning than did "interference."

\section{The Problems Remaining}

"Dishonesty" can hardly be described as a term fixed in either lay or legal meaning. ${ }^{89}$ But however vague the word may be, it does suggest some

84. Id. at 188 .

85. Id. at 189 .

86. Compare Schenck v. United States, 249 U.S. 47 (1919) (prosecution for conspiracy to violate a statute proscribing the obstruction of recruitment in time of war).

87. See the definitions of "deceive" and "defraud" in Williaurs, CRImINaL Law 76-77 (1953).

88. Even this restriction has on occasion been overlooked. E.g., the instruction of the trial judge quoted in Caywood v. United States, 232 F.2d 220, $225 \mathrm{n} .2$ (9th Cir.), cert. denied, 351 U.S. 983 (1956).

89. "Dishonest" is defined as follows: "1. a Dishonorable; shameful. b Indecent; unchaste; lewd. c Dishonored; disfigured; repulsive. 2. Characterized by fraud; indi- 
characteristics that "interference" does not. Although every crime interferes with some lawful function of government in the sense that it runs counter to a power lawfully exercised by the legislature, not every crime involves dishonesty. Crimes of violence-murder and manslaughter, assault and battery, mayhem and rape-would not seem to involve dishonesty in their perpetrators. Nor-at least according to Hammerschmidt-would burglary or robbery be included among the dishonest means out of which a charge of conspiracy to defraud the United States might develop. ${ }^{90}$ Thefts, without threats of violence, would, however, seem to retain their dishonest character, ${ }^{91}$ as would bribery or abuse of a relationship of trust. ${ }^{912}$ Apparently, then, one may be violent without being dishonest. But may one really be violent for purposes of pecuniary gain and not be dishonest? Certainly, the man on the street would find it difficult to believe that the thief is dishonest; and the robber or burglar, not. Similarly, is it not arguable that every crime-even one of violence-involves dishonesty when the offender acts with specific intent to violate the law? The answer would seem to depend upon one's estimate of the importance of law-abidingness as a measure of ethical behavior, just as the dishonesty clearly connoted by theft and less clearly connoted by robbery and burglary depends ultimately upon the value attached to the institution of property.

Obviously, the fact that "dishonest" suggests some things which "interfere" does not is hardly a reason for considering it a satisfactory measure of criminal liability. It leaves too many problems. Does $A$ 's breach of his contract with the Government constitute interference with a governmental function by "dishonest means" ? ${ }^{92}$ Certainly, the phrase is vague enough to expose $A$ to the

cating a want of probity; knavish, fraudulent; unjust; ... 3. Wanting in honesty or integrity; disposed to cheat or defraud; not trustworthy. . .." MERRIAM-WEBSTER, NEw InTERNational Dictionary 748 (2d ed. 1957). When the term "dishonest" is used in an insurance contract, its meaning is to be determined by "an appeal . . . to the mores rather than to the statutes. Dishonesty, unlike embezzlement or larceny, is not a term of art. Even so, the measure of its meaning is not a standard of perfection, but an infirmity of purpose so opprobrious or furtive as to be fairly characterized as dishonest in the common speech of men." Fidelity \& Deposit Co. v. Bates, 76 F.2d 160, 167 (8th Cir. 1935), quoting Cardozo, J., in World Exch. Bank v. Commercial Cas. Ins. Co., 255 N.Y. 1, 5, 173 N.E. 902, 903 (1930); see Commercial Banking Corp. v. Indemnity Ins. Co. of North America, 1 F.R.D. 380, 382 (E.D. Pa. 1940) ; Mitchell v. Morris, 129 La. 543, 56 So. 502 (1911).

90. 265 U.S. at 188; accord, Fasulo v. United States, 272 U.S. 620, 628-29 (1926) (use of the mails for the purpose of obtaining money by means of threats of murder or bodily harm did not involve a scheme to defraud, within the meaning of the mail fraud statute).

91. Cagle v. United States, 3 F.2d 747 (6th Cir. 1925) (conspiracy to defraud the United States is an appropriate charge where property in possession of the Government has been wrongfully taken).

91a. In addition to the cases cited note 108 infra, see the cases decided under the mail fraud statute, c.g., Shushan v. United States, 117 F.2d 110, 115 (5th Cir. 1941); United States v. Buckner, 108 F.2d 921, 927 (2nd Cir. 1940).

92. United States v. Byers, 73 F.2d 419 (2d Cir. 1934) seems to suggest that conspiracy to defraud the United States must involve fraud in the inducement:

[W] e think that a conspiracy to sell contrary to an agreement or regulation not to do so, if entered into after title to the goods had passed, would not constitute the 
risk of prosecution. How would he defend such a case? Would he have to show a good business reason for the breach? Would a frivolous breach constitute interference by dishonest means, on the theory that one who contracts with the Government owes it a continuing obligation of responsible performance? If the contract obligation is based on an implied promise to perform and a continuing representation that performance is forthcoming, dishonesty could be inferred from a failure to adhere to the implied promise and representation. The history of the conspiracy statute gives every reason for thinking that such an interpretation might be adopted. And if it were, imprisonment would have been made possible in a situation in which the civil courts ordinarily refuse even to permit punitive damages. ${ }^{93}$

Another class of problem is illustrated by $A$ 's direction to a bank official to keep $A$ 's bank records from an internal revenue agent who is trying to ascertain whether $A$ owes additional taxes. Arguably, everyone has the right to keep his affairs private unless an affirmative duty of disclosure has been imposed through a valid exercise of governmental power. On the other hand, the tax authorities unquestionably are authorized to conduct investigations looking to the ascertainment of tax liability. If the "conspiracy to defraud" statute is said to guard that authority, the problem arises of how to draw a line between the area in which one may act with complete impunity in personal affairs and the area in which impunity ends and an obligation to act "honestly" begins. Is there "dishonest interference" with an internal revenue agent investigating tax liability when an individual refuses to make his bank records available to the agent? The response of one sensitive to a tradition that crimes must be clearly defined by the legislature in terms comprehensible to men of common intelligence is that such an act can constitute "dishonest interference" only if a statute or a properly promulgated regulation imposes an obligation to disclose to the revenue agent. The existence of an elaborate investigative machinery, provided by statute and empowering the agent to obtain a subpoena, ${ }^{94}$ would seem to negate by implication the obligation to make disclosure outside the formal setting.

crime of conspiracy to defraud the United States. ... To conspire to break a contract with the United States or to violate its regulations, after title had passed, would seem to involve no such fraud as the purchasing of government supplies with the intention not to abide by a fixed understanding.

Id. at 422. But see Langer v. United States, 76 F.2d 817 (8th Cir. 1935), in which conspiracy to defraud the United States was held to exist where Governor Langer and others "assessed" persons working on programs financed by the RFC for contributions to support a political newspaper. Though this "assessment" plan does not appear to have preceded, or coincided with, the application for RFC funds, it was held to be part of a conspiracy to obstruct the proper use of the RFC funds: "A conspiracy to use the power of position to compel contributions out of such salaries . . . would obstruct the administration of the statute and the accomplishment of its purposes, because efficiency and morale might thereby be lowered." Id. at 824 .

93. MCCorMick, Damages $\$ 81$, at 289-90 (1935).

94. See generally Balter, Fraud UNDER Federal TAx LAw 225-29 (1951). Current provisions dealing with the investigation problem are INT. REv. CoDE of 1954, §§ 7602-06. These are virtually identical with the earlier code provisions discussed by Balter. 
But does the existence of the formal investigative apparatus really permit $A$ to refuse to cooperate in advance of its invocation, without relying upon the privilege against self-incrimination? Or does the phrase "defraud the United States" of itself impose the obligation to disclose, separate and apart from the pronouncements of any other statute, civil or criminal? In short, is a federal common law, imposing duties of disclosure, to be fashioned out of the words "defraud the United States"? If it is, then additional questions must be answered. Does the agreement to use "dishonest means" in some area regulated or regulable by the Government constitute interference, without more? Or is it necessary to show that the "dishonest means" would have interfered with the functioning of the Government, if consummated? Would any activity of a government officer-whether the result of express statutory authority or of his interpretation of the statute after a series of administrative delegationsbe the kind of government function which would render one who interfered with the activity by "dishonest means" a criminal? To what extent does criminal liability follow a failure to disclose information which has not been requested but which, if disclosed, would clearly facilitate the workings of the Government? Is there, for example, a duty to inform the Federal Bureau of Investigation about matters which would better enable it to apprehend law violators, even when a violation of the law is only suspected ?95

Some of these problems were raised but, unfortunately, not answered in United States $v$. Klein. ${ }^{96}$ Nine defendants had been charged in four counts with income tax evasion and conspiracy to evade income taxes, and, in a fifth count, with conspiracy to defraud the United States by "interfering with a lawful function of government; to wit, collection of income taxes." The "interference" was said to consist not of a failure to pay taxes as they became due nor even of an attempt to evade a tax ultimately found to be owing. ${ }^{97}$ Indeed, at the close of the Government's case, a judgment of acquittal was entered on

95. The federal misprision of felony statute makes it a crime for a person to conceal his knowledge of the "actual commission" of a felony. 18 U.S.C. \& 4 (1952). But it has been used very sparingly. See, e.g., Bratton v. United States, 73 F.2d 795 (10th Cir. 1934) :

If any meaning is to be given [to the word "conceal"] . ., an indictment must allege something more than mere failure to disclose-some affirmative act of concealment, such as suppression of the evidence, harboring of the criminal, intimidation of witnesses, or other positive act designed to conceal from the authorities the fact that a crime has been committed. Furthermore, some such interpretation is necessary to rescue the act from an intolerable oppressiveness and to eliminate a serious question of constitutional power.

Id. at 797. See also Note, Misprision of Felony, 6 S.C.L.Q. 87 (1953).

96. 247 F.2d 908 (2d Cir. 1957), cert. denied, 355 U.S. 924 (1958). The author, together with F. Joseph Donohue of the District of Columbia Bar, was counsel for the defendant Alprin throughout the trial and appeal.

97. Record, pp. 6295-96, 8809, 9256, Briefs for Appellants, app., vol. 2, pp. 898-99, vol. 4, 2446-47, 2575, United States v. Klein, sipra note 96 . See also United States v. Klein, 139 F. Supp. 135, 141-43 (S.D.N.Y. 1955). 
the first four counts because the Government had not proved tax liability. ${ }^{98}$ Defendants were convicted instead on the fifth count of conspiracy to prevent the Treasury from learning about the very taxes which were not owed. The charge which took the case to the jury was rooted in allegations of concealment: that defendants had so arranged their business activities as to prevent Treasury agents from learning the true facts about the income earned by the Harwood Whiskey enterprise. In the trial judge's vivid phrase, the defendants were on trial for conspiring "to throw sand in the government's eyes." Liability could exist even if the Government was not looking at the time the sand was thrown and even if it turned out that, because there was no tax liability, there was nothing to hide.

Of course, no one can quarrel with the proposition that one who commits a crime in pursuit of a larger objective which he believes to be a crime but which proves not to be, is guilty of the intermediate crime. Thus, if the defendants in Klein had committed perjury, made false statements, or filed false tax returns, they could have been found guilty of each of those crimes. And if they had conspired to commit any of these crimes but had not succeeded in consummating them, they could have been prosecuted under the "offense" portion of the conspiracy statute. But since intermediate crimes, or conspiracies to commit them, if they existed, were neither charged in the indictment nor given to the jury in the form of instructions, the conviction which followed depended entirely upon whether "fraudulent" means were used by the defendants to interfere with the tax-collection function of the Treasury Department.

To the extent that those means included falsehoods to induce action by government officials, they fell within the most conventional understanding of fraud. But in so far as concealment of information alone was the means alleged, as it was in considerable part, a new dimension was added. "Concealment," like "fraud," is an epithetical word which depends for its significance upon the existence of an obligation. While everyone will agree that there is an obligation not to lie in response to a lawful inquiry by the Government, such a consensus is not likely to exist when an obligation to volunteer information is in question. Because imposition of the latter duty intrudes upon self-determination and privacy, it can as easily be classed an invasion of the right to do what one wishes with one's own as it can be styled "concealment"-unless, of course, a statute imposes the obligation to disclose. ${ }^{100}$

98. United States v. Klein, 139 F. Supp. 135 (S.D.N.Y. 1955).

99. 139 F. Supp. at 141 ; Record, p. 9236 ; Briefs for Appellants, app., vol. 4, p. 2561 (charge to jury).

100. Just how "concealment" becomes an unlawful object of conspiracy under 18 U.S.C. $\$ 371$ (1952) - except to the extent that it is brought in under a specific statutory offense such as misprision of felony, note 95 supra, or through "defrauding"-is not clear. Nevertheless, in both Krulewitch v. United States, 336 U.S. 440, 443-44 (1949), and in Grunewald v. United States, 353 U.S. 391, 399-406 (1957), the Court assumes that when concealment of the main object of a conspiracy is itself a part of the original agreement, the life of the conspiracy is extended for as long as the concealment continues, for purposes both of admitting what would otherwise be hearsay and of extending the statute of limitations. 
The trial judge in Klein disregarded the suggestion that only one source could exist for the obligation to disclose facts from which income tax liability could be ascertained-the Internal Revenue Code. ${ }^{101}$ Instead, he told the jury that its function was to determine whether the defendants had conspired "to conceal from the Government . . . information . . . to which it was entitled ...."102 Although "there is no obligation on a taxpayer to volunteer information which might invite a searching analysis of his and his associates' transactions for the purpose of ascertaining or verifying tax liability," there is an obligation on such persons "to demean themselves honestly and not to conceal from the tax authorities the business relationships of such persons and the nature and source of their income."103 Again: "The United States in performing its governmental function of assessing and collecting income taxes, is under our law entitled to the economic facts upon which the proper tax is to be computed. It is the duty of everyone in our country to supply those facts as required by law."104 And finally: "Except where disclosure is required by proper legal authority, every person and every corporation is entitled to maintain the privacy of his or its business, books, papers, and documents and to prevent others from inspecting them."105

The concealment-obligation nexus was clearly articulated; but when it came to identifying the source of the obligation, the charge retreated to language like "entitled," "required by law" and "honest." The promise implicit in each of the judge's sentences-that explanation would soon follow to make clear just which provision of law required the defendants to disclose what information to whom-was never fulfilled. No statute or regulation imposing a duty to disclose specified information to a particular officer was cited. The only guide given the jury for determining what obligation, if any, the defendants owed to their Government was the paraphrase from Hammerschmidt-that a conspiracy to defraud the United States by interference with a lawful government function is made out if the interference is sought to be accomplished by "deceit, craft or trickery or at least by means that are dishonest." 106 The opinion of the Second Circuit offered no more in the way of explanation. ${ }^{107}$

101. See, e.g., Record, pp. $8809-13$ (esp. 8812) ; Briefs for Appellants, app., vol. 4, pp. 2446-49 (esp. 2448-49).

102. Record, p. 9246; Briefs for Appellants, app., vol. 4, p. 2568.

103. Record, p. 9250; Briefs for Appellants, app., vol. 4, p. 2571.

104. Record, p. 9257; Briefs for Appellants, app., vol. 4, p. 2575.

105. Record, p. 9267; Briefs for Appellants, app., vol. 4, p. 2582.

106. 265 U.S. at 188 .

107. Judge Clark conceded that "mere failure to disclose income would not be sufficient" to constitute the "defrauding" contemplated by $\S 371$. 247 F.2d at 916. Presumably, then, something more affirmative was necessary. Compare Bratton v. United States, 73 F.2d 795, 797 (10th Cir. 1934). But his sole reference for that "something" was to one portion of the evidence dealing with alleged misrepresentation of income as capital gain, a segment of the case amply covered by the obligations spelled out in the Internal Revenue Code. $247 \mathrm{~F} .2 \mathrm{~d}$ at 916 . But, as indicated in the text, other substantial elements of the case dealt with "concealment" of activities in no way covered by the Internal Revenue Code or any other statute or regulation. The trial judge did not limit his charge to the alleged 
The point which Klein so clearly illuminates comes, then, substantially to this: though it may be possible to class already established crimes or torts as conduct either involving or not involving dishonesty, it is quite another matter to use so broad a phrase as "dishonest means" as the heart of a definition of a major crime. When it is stripped, as it has been, of its roots in the law of theft, fraud and perjury, "dishonesty" stands only as an incorporation into the criminal law of current ethical standards-whatever a jury may think them to be. And any agreement to behave unethically in dealings with the Government, which behavior might in some measure impair the efficient operation of one of the Government's myriad activities, could be drawn within the ambit of conspiracy to defraud the United States. So broad a statutory construction violates that most fundamental precept of a government of delegated powers, that silence, privacy and freedom from interference are the normal operative rules, and that obligations to disclose one's affairs to the Government, particularly when criminal sanctions loom in the background, must be clearly imposed by the legislature.

\section{Categorizing the Cases}

Thus far, detailed consideration has been given to the conceptual evolution of the phrase "defraud the United States." It is somewhat unclear-because so much of the trial process is lost to all but the participants-whether the cases have in fact rested upon as broad an application of that phrase as judicial interpretations would seem to allow. Nevertheless, the reported decisions lend themselves to some meaningful generalizations. The cases fall into six categories.

1. Agreements to interfere with the administration of official duties, initiated by corrupt officials themselves, or by others' corrupting government officials so that they will act for their personal gain and against the interests of the United States. Though false statements may incidentally be involved, the main thrust is bribery or a similar device used to corrupt. ${ }^{108}$

2. Agreements to use practices recognized as frauds at common law, such as false statements or impersonations, by persons dealing with the Government in

violations of obligations imposed upon the defendants by statute or regulation. Record, p. 9256; Briefs for Appellants, app., vol. 4, pp. 2575-76. The jury could, therefore, have found the defendants guilty even if it believed them to be innocent of any violation of duty specifically imposed upon them by statute or regulation.

108. Grunewald v. United States, 353 U.S. 391 (1957) ; Haas v. Henkel, 216 U.S. 462 (1910) ; Crawford v. United States, 212 U.S. 183 (1909) ; Connelly v. United States, 249 F.2d 576 (8th Cir. 1957) ; Joyce v. United States, 153 F.2d 364 (8th Cir.), cert. denied, 328 U.S. 860 (1946) ; Braatelien v. United States, 147 F.2d 888, 893-95 (8th Cir. 1945); United States v. Harding, 81 F.2d 563 (D.C. Cir. 1936) ; Langer v. United States, 76 F.2d 817 (8th Cir. 1935) ; Browne v. United States, 290 Fed. 870 (6th Cir. 1923) ; Stager v. United States, 233 Fed. 510 (2d Cir. 1916) ; Tyner v. United States, 23 App. D.C. 324 (D.C. Cir. 1904); United States v. Cohen, 113 F. Supp. 955 (S.D.N.Y. 1953); United States v. MicConnell, 285 Fed. 164 (E.D. Pa. 1923) ; In re Runkle, 125 Fed. 996 (C.C.S.D.N.Y. 1903); United States v. Greene, 115 Fed. 343, 353 (E.D. Ga. 1902), cert. denied, 207 U.S. 596 (1907); United States v. Van Leuven, 62 Fed. 62 (N.D. Iowa 1894). 
arm's-length business relationships, in order to obtain money, property, contracts or benefits provided by law. ${ }^{109}$

3. Agreements to steal or "convert" money or property of the Goverment or its instrumentality. ${ }^{110}$

4. Agreements to defeat the administration of justice in the federal courts or in administrative agencies, either through bribery, perjured testimony or the obtaining of bail by false statements. ${ }^{111}$

5. Agreements to deprive the Government of taxes or customs dutiesby means of false tax returns or by smuggling or secreting goods or by mislabeling them so that taxable items appear to be nontaxable. ${ }^{112}$

109. The land cases, some of which are cited in note 49 supra, illustrate the range of situations under this head. But the category also includes (a) the obtaining of government contracts by misrepresentation or by collusion among bidders: Houston v. United States, 217 Fed. 852 (9th Cir. 1914), cert. denied, 238 U.S. 613 (1915); McGregor v. United States, 134 Fed. 187 (4th Cir. 1904) ; United States v. Union Timber Prod. Co., 259 Fed. 907 (W.D. Wash. 1919) ; (b) inducing payment for defective or substandard goods delivered to the Government: Nye \& Nissen v. United States, 336 U.S. 613, 615, 617 (1949) ; United States v. Samuel Dunkel \& Co., 184 F.2d 894 (2d Cir.), cert. denied, 340 U.S. 930 (1950) ; Mininsohn v. United States, 101 F.2d 477 (3d Cir. 1939); Wolf v. United States, 283 Fed. 885 (7th Cir.), cert. dentied, 260 U.S. 743 (1922); Keane v. United States, 272 Fed. 577 (4th Cir. 1921) ; (c) inducing payment for work not done at all, or for padded cost items or for other "fraudulent" claims: United States v. Walter, 263 U.S. 15 (1923) ; United States v. Benson, 70 Fed. 591 (9th Cir. 1895) ; United States v. Reichert, 32 Fed. 142 (C.C.D. Cal. 1887) ; United States v. United States Brokerage \& Trading Co., 262 Fed. 459 (S.D.N.Y. 1919); United States v. Carlin, 259 Fed. 904 (E.D. Pa. 1917); United States v. Newton, 52 Fed. 275 (S.D. Iowa 1892); United States v. Adler, 49 Fed. 736 (S.D. Iowa 1892) ; United States v. Dennee, 25 Fed. Cas. 818 (No. 14948) (C.C.D. La. 1877 ) ; (d) inducing payment of money or property by the Government for reasons which did not qualify the defendants as proper recipients under the applicable statute or regulations: Green v. United States, 28 F.2d 965, 968 (8th Cir. 1928) ; Falter v. United States, 23 F.2d 420 (2d Cir. 1928), cert. denied, 277 U.S. 590 (1928) ; United States v. Weinberg, 129 F. Supp. 514 (M.D. Pa.), aff'd, 226 F.2d 161 (3d Cir. 1955), cert. denied, 350 U.S. 933 (1956) ; United States v. Atlanta Journal Co., 185 Fed. 656 (C.C.N.D. Ga. 1911), appeal dismissed, 229 U.S. 605 (1912) ; United States v. Whalan, 28 Fed. Cas. 531 (No. 16669) (D. Mass. 1868).

110. Reynolds v. United States, 67 F.2d 216 (9th Cir. 1933) ; Cagle v. United States, 3 F.2d 746 (6th Cir. 1925).

111. Glasser v. United States, 315 U.S. 60 (1942); United States v. Manton, 107 F.2d 834 (2d Cir. 1939), cert. denied, 309 U.S. 664 (1940) ; Outlaw v. United States, 81 F.2d 805 (5th Cir.), cert. denicd, 298 U.S. 665 (1936) ; Cendagarda v. United States, 64 F.2d 182 (10th Cir. 1933) ; Asgill v. United States, 60 F.2d 780 (4th Cir. 1932); Tyson v. United States, 54 F.2d 26 (5th Cir. 1931), cert. denied, 285 U.S. 551 (1932); United States v. Sager, 49 F.2d 725 (2d Cir. 1931) ; Eddington v. United States, 24 F.2d 50 (8th Cir. 1928) ; Henry v. United States, 15 F.2d 624 (9th Cir. 1926), cert. denied, 274 U.S. 737 (1927) ; Radford v. United States, 129 Fed. 49 (2d Cir. 1904). See also Joyce v. United States, 153 F.2d 364 (8th Cir.), ccrt. donied, 328 U.S. 860 (1946); Braatelien v. United States, 147 F.2d 888 (8th Cir. 1945).

112. United States v. Hirsch, 100 U.S. 33 (1879) ; United States v. Goldstein, 135 F.2d 359 (2d Cir. 1943) ; United States v. Harrison, 121 F.2d 930 (3d Cir.), cert. denied, 314 U.S. 661 (1941) ; Jelke v. United States, 255 Fed. 264 (7th Cir. 1918) ; Browne v. United 
6. Agreements to defraud by interfering with a lawful function of government, usually in ways similar to those set out above, but where the charge is cast principally in terms of "interference" or "obstruction."113

The pattern of conduct which emerges from these six categories and from the hundred-odd opinions they represent involves, in almost every case, an agreement to violate some statute creating a substantive crime or a noncriminal "offense." The bribery, graft and concealment which characterize many of the cases in the first and fourth categories are now reached by statutes specific-

States, 145 Fed. 1 (2d Cir. 1905), cert. denied, 200 U.S. 618 (1906) ; United States v. Olmstead, 5 F.2d 712, 713 (W.D. Wash. 1925), cert. denied, 275 U.S. 557 (1927) ; United States v. Orr, 223 Fed. 220 (D.R.I. 1915) ; United States v. Shevlin, 212 Fed. 343 (D. Mass. 1913); United States v. Stamatopoulos, 164 Fed. 524 (C.C.E.D.N.Y. 1908); In re Calicott, 4 Fed. Cas. 1051 (No. 2311) (C.C.N.D.N.Y. 1868) ; United States v. Whalan, 28 Fed. Cas. 531 (No. 16669) (D. Mass. 1868) ; cf. Lisansky v. United States, 31 F.2d 846, 849 (4th Cir.), cert. denied, 279 U.S. 873 (1929). Several cases might be listed within this category in which, although the fraud involved has been made a substantive offense, the discussion is in terms of conspiracy to defraud. See, e.g., United States v. Johnson, 319 U.S. 503 (1943); Becher v. United States, 5 F.2d 45 (2d Cir. 1924), cert. denied, 267 U.S. 602 (1925).

113. In addition to Curley, Haas, Hammerschmidt and Klein, see Bridges v. United States, 346 U.S. 209, 212-13 (1953) (false statement) ; Lutwak v. United States, 344 U.S. 604 (1953) (misrepresentations); Fiswick v. United States, 329 U.S. 211 (1946) (false statements and nondisclosures); Schino v. United States, 209 F.2d 67 (9th Cir. 1953), cert. denied, 347 U.S. 937 (1954) (bribery); Heald v. United States, 175 F.2d 878 (10th Cir.), cert. denied, 338 U.S. 859 (1949) (false statements); Berenbeim v. United States, 164 F.2d 679 (10th Cir. 1947), cert. denied, 333 U.S. 827 (1948) (false statements and other misrepresentations); Canella v. United States, 157 F.2d 470 (9th Cir. 1946) (bribery); Joyce v. United States, 153 F.2d 364 (8th Cir.), cert. denied, 328 U.S. 860 (1946) (inducing farmers to file false bankruptcy petitions, thereby interfering with the administration of the Frazier-Lemke amendment to the Bankruptcy Act) ; Hills v. United States, 97 F.2d 710 (9th Cir. 1938) (false statement) ; Miller v. United States, 24 F.2d 353 (2d Cir.), cert. denied, 276 U.S. 638 (1928) (bribery); Horwitz v. United States, 5 F.2d 129, 130 (1st Cir. 1925) (concealment of contraband from customs); Rumely v. United States, 293 Fed. 532 (2d Cir.), cert. denied, 263 U.S. 713 (1923) (concealment of assets to prevent their seizure by the Alien Property Custodian) ; Hamburg-American Steam Packet Co. v. United States, 250 Fed. 747 (2d Cir.), cert. denied, 246 U.S. 662 (1918) (false shipping manifests); Curley v. United States, 130 Fed. 1 (1st Cir. 1904), cert. denied, 195 U.S. 628 (1904) (impersonation) ; Palmer v. Colladay, 18 App. D.C. 426 (D.C. Cir. 1901) (false statements) ; United States v. O’Toole, 101 F. Supp. 123 (D.R.I. 1951) (forgery and misrepresentations); United States v. Kendzierski, 54 F. Supp. 164 (E.D.N.Y. 1944) (false statements); United States v. Rhoads, 48 F. Supp. 175, 176 (D.D.C. 1942) (delaying production of war material); United States v. Furer, 47 F. Supp. 402,405 (S.D. Cal. 1942) (depriving Government of competitive bidding on government contracts; bribery of employee of general contractor not classed as an officer of the United States within the meaning of the bribery statute) ; United States v. Soeder, 10 F. Supp. 944 (W.D. Mo. 1935) (misrepresentations); United States v. Terranova, 7 F. Supp. 989 (N.D. Cal. 1934) (failure of government sub-contractors to pay minimum wages); United States v. Fung Sam Wing, 254 Fed. 500 (N.D. Cal. 1918) (misrepresentations in violation of Chinese Exclusion Laws); United States v. Morse, 161 Fed. 429 (C.C.S.D.N.Y. 1908), aff'd, 174 Fed. 539 (2d Cir. 1908), cert. denied, 215 U.S. 605 (1909) (false statements and misapplication of funds); United States v. Stone, 135 Fed. 392 (D.N.J. 1905) (misrepresentations). 
ally directed at the objectionable conduct in question. ${ }^{114}$ The false statements and false claims which pervade the second category violate the substantive criminal statutes which punish perjury or false statements made to agencies of the United States or the presentation of false claims to them, ${ }^{115}$ though falsehood is not always treated as the gist of the conspiracy. The third category clearly mirrors the law of theft.110 The fourth category simply identifies the false statements and bribes in the first two categories with the institutions involved in the administration of justice. Each of them-bribery, perjury and the use of falsehood to obtain a bail bond-is now specifically made criminal by statute. ${ }^{117}$ The same is true of the fifth category, which is now blanketed by specific crimes dealing with the evasion of taxes ${ }^{118}$ or with smuggling, ${ }^{119}$ or by statutes which clearly brand certain defined conduct as an "offense" carrying a penalty. ${ }^{120}$

The sixth category, whose outlines are traced by Haas and Hammerschmidt, is, of course, the one which has caused the greatest difficulty. But here, too, close analysis reveals that virtually all of the cases decided within it fit also into one or more of the five other categories. ${ }^{121}$ The interferences with government punished in these cases ordinarily involves false statements or claims, bribes or violations of obligations imposed by statute-either criminal or noncriminal.

If the means ordinarily used to defraud the Government are separately prohibited by statute, then each of them would appear to be an "offense." Why, then, are they not prosecuted under the first half of the conspiracy statute, which reaches conspiracy to commit "any offense" against the United States? As already suggested, the reasons lie partly in history, partly in faulty analysis and partly in tactical considerations.

114. See, e.g., 18 U.S.C. $\$ \S 152-55$ (1952) (bankruptcy proceedings: concealment of assets, false oaths and claims, bribery, embezzlement, adverse interests, etc.) ; 18 U.S.C. \$ 201-23 (1952) (bribery and graft, both generally and with reference to particular officers and agencies); 18 U.S.C. $\$ \$ 281-84,431-43$ (1952) (conflict of interest provisions).

115. The general perjury and false statement statutes may be found at 18 U.S.C. $\S \S$ 1001, 1621 (1952). For other, more particular, false claims provisions, see 66 Stat. 225 (1952), \& U.S.C. $\$ 1306$ (c) (1952) ; 48 Stat. 49 (1933), 12 U.S.C. $\$ 1019$ (1952); 13 U.S.C. $\S 213$ (1952); 42 Stat. 855 (1922), 15 U.S.C. $\S 158$ (1952); 18 U.S.C. $\S \S 286-89$, $541,542,550,1002-26,1424-26, .1542,1712$ (1952) ; 54 Stat. 918 (1940), 49 U.S.C. \& $20(7)(b)(1952)$.

116. "Theft" (including embezzlement), as a federal crime, is restricted to theft of public money, property, or records, or thefts arising out of specifically enumerated activities of the Government. 18 U.S.C. $\$ \S 641-63$ (1952).

117. 18 U.S.C. $\$ \S 201-23,1503-06,1621$ (1952).

118. INT. REv. CoDE of 1954, $\$ 7201$. The comparable provision of the Int. Rev. Code of 1939 was ch. 289 , \& 145(b), 52 Stat. 513 (1938).

119. 18 U.S.C. $\$ 545$ (1952).

120. Compare Int. Rev. Cone of 1954, §§ 7261-344 with INT. Rev. Code of 1954, § 7401 in the light of the principle discussed in the Hutto, Wiesner, and Winner cases, note 23 supra.

121. See note 113 supra. 
When the statute was first adopted in 1867, the federal criminal code was in a primitive state. It contained only a handful of substantive crimes, and experience with them was limited. ${ }^{122}$ For a long time, for example, the reach of the false-statement and false-claims statutes was not at all clear. ${ }^{123}$ Laws dealing specifically with various types of frauds, such as those on the mail or on the revenue, or with particular methods of obstructing justice, were not enacted until later. And the detailed network of statutes designed to reach the corruptible government official had not yet come into existence. With the activities of the federal government fast outstripping the ability of Congress to fashion criminal statutes to guard federal processes, it was hardly unexpected that federal prosecutors would search for an appropriate catch-all category into which they could fit such conduct as they (and perhaps the prevailing mores) deemed to be deserving of punishment. The impact of such pressure upon words of seemingly settled meaning has already been traced.

But times have changed. The problem today is not one of gaps in the criminal code but of overlapping offense categories which multiply the sanctions that can be imposed for a single course of antisocial conduct. ${ }^{124}$ The gaps have been filled and filled again, through enactment of specific criminal statutes. This open-end crime remains on the books nevertheless, and not only as the vestigial remnant of another day. Quite the contrary. Contours molded by almost a century of decision are not so easily lost. The vigor of "conspiracy to defraud the United States," at least as measured quantitatively, continues unabated.125

But where its primary function once was to reach conduct not covered elsewhere in the criminal code, it now serves its original purpose in very limited fashion. Its main significance today is in the field of tactics. Given the choice, a prosecutor will invariably choose to proceed under the statute which affords him the maximum flexibility in framing his charge and presenting his proof. The addition to the conspiracy count (already described as the prosecutor's "darling") $)^{126}$ of the loosely-defined concept of fraud makes conspiracy "to

122. See note 44 supra.

123. See notes 50-52 supra and accompanying text.

124. See Kirchheimer, The Act, The Offense and Double Jeopardy, 58 YaLE L.J. 513 (1949); Comment, Statutory Implementation of Double Jeopardy Clauses: New Lifc for a Moribund Constitutional Guarantee, 65 YALE L.J. 339 (1956); Note, Consecutive Sentences in Single Prosecutions: Judicial Multiplication of Statutory Penalties, 67 YALE L.J. 916 (1958).

125. Though the Department of Justice does not have any statistics indicating the frequency of prosecutions under $\S 371$-because its "statistics are compiled on the basis of the substantive offense rather than upon an offense where Section 371 might be involved" (Letter from G. Frederick Mullen, Director of Public Information, U.S. Dep't of Justice, to the author, June 28, 1957) - the bulk of the reported decisions involving conspiracy to defraud the United States-a fraction of the total number of prosecutions for this crimeis considerable. J.).

126. Harrison v. United States, 7 F.2d 259, 263 (2d Cir. 1925) (per Learned Hand, 
defraud the United States" peculiarly attractive to the prosecutor and particularly subversive of principles deeply rooted in our criminal law.

\section{The Problem of Vagueness}

All the evils against which the "void for vagueness" doctrine is said to guard exist in "conspiracy to defraud the United States" as interpreted by the Supreme Court. The phrase certainly has no meaning which can be understood by "men of common intelligence."127 Surprisingly, however, the Court has never passed on the constitutionality of the crime, although it came close in Gradwell. ${ }^{128}$ The one court of appeals discussion of the problem is hardly satisfactory. The court found the requirement of definition satisfied by the statute's use "of words [which have a] settled meaning or which indicate offenses well known to and defined by the common law."129 But, as already

127. "[A] statute which either forbids or requires the doing of an act in terms so vague that men of common intelligence must necessarily guess at its meaning and differ as to its application, violates the first essential of due process of law." Connally v. General Constr. Co., 269 U.S. 385, 391 (1926). The doctrine that a criminal statute, if sufficiently vague, violates the due process clause of the fifth or fourteenth amendment has been developed in a long line of cases. In addition to Connally, supra, see United States v. Harriss, 347 U.S. 612, 617 (1954); Jordan v. DeGeorge, 341 U.S. 223, 230 (1951); Musser v. Utah, 333 U.S. 95, 96-97 (1948) ("Iegislation may run afoul of the Due Process Clause because it fails to give adequate guidance to those who would be law-abiding, to advise defendants of the nature of the offense with which they are charged, or to guide courts in trying those who are accused."); Winters v. New York, 333 U.S. 507, 518 (1948); United States v. Petrillo, 332 U.S. 1, 6-7 (1947); Lanzetta v. New Jersey, 306 U.S. 451, 453 (1939) ("It is the statute, not the accusation under it, that prescribes the rule to govern conduct and warns against transgression. . . . No one may be required at peril of life, liberty or property to speculate as to the meaning of penal statutes. All are entitled to be informed as to what the state commands or forbids."); United States v. L. Cohen Grocery Co., 255 U.S. 81,89 (1921) ; United States v. Capital Traction Co., 34 App. D.C. 592, 598-99 (D.C. Cir. 1910). See generally Freund, The Use of Indefinite Terms in Statutes, 30 YALE L.J. 437 (1921) ; Note, Due Process Requirements of Definiteness in Statutes, 62 HaRv. L. Rev. 77 (1948) ; Annot., 83 L. Ed. 893 (1939). Compare Nash v. United States, 229 U.S. 373, 377 (1913) (per Holmes, J.) ("The law is full of instances where a man's fate depends on his estimating rightly, that is, as the jury subsequently estimates it, some matter of degree."), with McBoyle v. United States, 283 U.S. 25,27 (1931) (" $[I] t$ is reasonable that a fair warning should be given to the world in language that the common world will understand, of what the law intends to do if a certain line is passed.").

A corollary of the "vagueness" doctrine is the rule requiring that a criminal statute be strictly construed. For a discussion of that rule, and of state statutes seeking to codify it, see Hall, Strict or Liberal Construction of Penal Statutes, 48 HARv. L. Rev. 748 (1935).

128. 243 U.S. at 485.

129. Crawford v. United States, 30 App. D.C. 1, 12 (D.C. Cir. 1907) (quoting from Czarra v. Medical Supervisors, 25 App. D.C. 443,450 (D.C. Cir. 1905)), rev'd on other groutus, 212 U.S. 183 (1909); cf. Connally v. General Constr. Co., 269 U.S. 385, 391 (1926) : "[T] he decisions of the court upholding statutes as sufficiently certain, rested upon the conclusion that they employed words or phrases having a technical or other special meaning, well enough known to enable those within their reach to correctly apply them . . . . or a well-settled common law meaning, notwithstanding an element of degree in the definition as to which estimates might differ." 
demonstrated, were a man of "common intelligence" to search long and hard for the "settled meaning," he would discover that neither "conspiracy" nor "defraud" possess it. The only "settled" aspect of the words is that they were known and used at common law-but always as concepts which had within them growth principles as dynamic as the standard of care in torts. ${ }^{13 n}$

The circuit court's opinion points to the paradox of treating words of "settled meaning" as general exceptions to the rule that the constitutionality of a criminal statute depends upon its meaningfulness to the man of "common intelligence." The very body of law from which the ideal of definition is allegedly drawn-the Anglo-American common law of crimes-is itself the end result of a process of retroactive creation of crime by the judiciary to meet the needs of a society in transition, by expanding old categories and creating new ones. Concepts born of such a process may, of course, be as specifically defined as those fashioned by a legislature. Unfortunately, however, the "settled meaning" exception assumes specificity even when none exists. Words known to the common law are automatically treated as precise and known to all. This is the case with "defraud the United States." Yet the phrase, as interpreted by the Supreme Court, is too vague to be understood by the man of "common intelligence." It should undoubtedly be held unconstitutional.

That it will be, however, is highly unlikely. Although they agree on the proper formula for decision, the "vagueness" cases have exhibited such diverse results that they cannot be expected to provide very much assistance. No federal statute has been held invalid on vagueness grounds in recent times. Even the state statutes which have met this fate have involved obvious first amendment questions or have embodied avowed catch-all categories unshielded by terms of "settled meaning."131 Probably no more can be expected from the vagueness

130. [W] hat is due care in driving cannot be determined in the abstract, once for all, for every driver who will ever drive. In cases of this sort the modern law resorts not to rules (as it ordinarily does in fields of property and commercial law) but to legal standards devised to guide tribunals in applying to each unique set of circumstances their common sense resulting from their experience. But this device of standards, which has proved so useful in the law of torts, in equity, and above all, in the law of public utilities, is not available, or is available only within narrow limits, in criminal law. The exigencies of the general security preclude resort to it. The policy which led our federal courts and so many of our states to reject common-law misdemeanors, and led in Continental Europe to the doctrine mella poena sine lege, no penalty without a rule of law, forbids our doing in criminal law what is done through the standards in so many fields of civil justice.

Pound, Criminal Justice in America 30-31 (1950).

131. See Musser v. Utah, 333 U.S. 95 (1948); Winters v. New York, 333 U.S. 507 (1948) ; Lanzetta v. New Jersey, 306 U.S. 451 (1939). Compare State v. Musser, 118 Utah 537, 223 P.2d 193 (1950) (decided subsequent to Musser v. Utah, 333 U.S. 95 (1948), and holding unconstitutional a statute making criminal conspiracies "to commit any act injurious ... to public morals"), and International Longshoremen's Union v. Ackerman, 82 F. Supp. 65, 104-06 (D. Hawaii 1949), rev'd on other grounds, 187 F.2d S60 (9th Cir. 1951) (holding unconstitutionally vague a statute making it a crime to conspire "to do what plainly and directly tends to excite or occasion offense, or what is obviously and directly wrongfully 
argument than that it will exert some leverage towards the framing of doctrines designed to narrow the reach of the statute. ${ }^{132}$

The influence of the vagueness argument will ultimately depend, of course, upon whether there is any contemporary justification for an elastic concept of conspiracy to defraud the Government. Many concededly vague crimes at the lower end of the criminal law spectrum-vagrancy, disorderly conduct and loitering, for example-have on occasion been rationalized as essential catchall devices enabling police and prosecutor to operate in a twilight zone-both by cloaking with legality otherwise illegal arrests on suspicion, and by reaching antisocial conduct which cannot be fitted into existing criminal categories. ${ }^{133}$ A similar rationale for vagueness is sometimes announced for both conspiracy and fraud. It is said, for example, that the man who will use deceit, craft or trickery is the man who will take a precise statement of what he may not do as an invitation to press hard upon the borders of legality. ${ }^{134}$ Fraud statutes must, therefore, be vague if they are to serve their function in a criminal code.

injurious to another"), with Lorenson v. Superior Court, 35 Cal. 2d 49, 59-61, 216 P.2d 859, 965-66 (1950) (upholding against a charge of vagueness a statute punishing conspiracy "to pervert or obstruct justice, or the due administration of the laws").

132. See United States v. Universal C.I.T. Credit Corp., 344 U.S. 218, $221-22$ (1952); Screws v. United States, 325 U.S. 91, 101-07 (1945).

133. See generally Hall, The Law of Arrest in Relation to Contemporary Social Problens, 3 U. CEI. L. Rev. 345, 369-70 (1936) ; Lacey, Vagrancy and Other Crimes of Personal Condition, 66 Harv. L. Rev. 1203 (1953); Note, Use of Vagrancy-Type Lazes for Arrest and Detention of Suspicions Persons, 59 Yale L.J. 1351 (1950).

134. See, e.g., Foshay v. United States, 68 F.2d 205, 211 (8th Cir. 1933) ("To try to delimit 'fraud' by definition would tend to reward subtle and ingenious circumvention and is not done") ; Stonemets v. Head, 248 Mo. 243, 263, 154 S.W. 108, 114 (1913) :

Fraud being infinite and taking on protean form at will, were courts to cramp themselves by defining it with a hard and fast definition, their jurisdiction would be cunningly circumvented at once by new schemes beyond the definition. Messieurs, the fraudfeasors, would like nothing half so well as for courts to say they would go thus far and no further in pursuit. ... Accordingly definitions of fraud are of set purpose left general and flexible, and thereto courts match their astuteness against the versatile inventions of fraud-doers.

After summarizing views similar to those above, Sheridan observes:

Give a definition of "fraud," it is said, and nasty people will immediately go and do something just not covered by the definition, but which still ought not to be allowed. To this there are three answers. In the first place, an act cannot necessarily be done with impunity because it is not fraud. Secondly, the definition should be so framed that the principles stated cover all cases held to be fraud. Thirdly, this work of definition is not legislation.

Sheridan, Fraud in Equity 1-2 (1957). See 8 Holdsworth, A History of English LAw 381-\$4 (1936); Bigelow, Definition of Frand, 3 L.Q. Rev. 419 (1887) ; Saeta, Prohibition and Hawkins' Doctrine, 66 U.S.L. Rev. 75, 77 (1932) ; cf. BRYAN, The DevelopMENT OF THE ENGLish LAW OF CoNSPIRACY 114 (1909): "The criminal liability thus created [by common-law concept of conspiracy] may well operate as a deterrent upon the pernicious activities of that considerable class of citizens who feel no scruple against engaging in almost any scheme of fraud or oppression not involving the doing of acts 
Whatever the merits of facilitating civil recoveries for fraudulent schemes, it hardly seems defensible to frame legislation carrying a possible five-year sentence so that persons are invited to rely on its permissions as well as its prohibitions and then, after that reliance, to decide that they have come too close. ${ }^{135}$ Such an approach is the very negation of a fundamental tenet of criminal law in the western world : that no one be punished for conduct which has not been legislatively defined and classed as a crime in advance of its commission. ${ }^{136}$ The notice-giving function reflected in this doctrine traces to

which are in themselves indictable offenses." But cf. WRIGHT, CRIMINAL Consprracies AND Agreenients 68 (1887):

In an imperfect system of criminal law the doctrine of criminal agreements for acts not criminal, may be of great practical value for the punishment of persons for acts which ought to be punishable irrespectively of agreement, and especially for some kinds of fraud; but this use of the doctrine involves an important delegation of a legislative power in a matter in which the exercise of such power ought to be carefully guarded, since the legislature admits its own inability to discover the principles on which legislation ought to proceed.

See also Sayre, Criminal Conspiracy, 35 Harv. L. Rev. 393, 421-22 (1922).

135. Consider, e.g., the interesting case of United States v. Weinberg, 226 F.2d 161 (3d Cir. 1955), cert. denied, 350 U.S. 933 (1956), in which the defendants, who conducted a school which qualified for veterans' studies, organized a corporation to sell supplies to the school. Their alternative would have been to purchase the supplies from similar corporations at arm's length, in which event the cost to the Government would have been identical but the profits to the defendants less. Neither manipulation of accounts nor false entries was involved. Said the court:

The vice of the situation... was not entries false on their face but the basic wrong of foisting upon the true expense for the schools, the school owners and managers themselves as an utterly unnecessary selling agent which collected an unconscionablc profit completely contrary to the intent of the Act.

[T] he validity of the corporate organization of Mercury [the defendants' corporation] is not material. Nor do we dispute the right of a bona fide middleman in appropriate circumstances to a legitimate profit. Here, however, the formation of Mercury by the school directors constituted an important step in their scheme to defraud the Veterans Administration, an agency of the United States, by inflating the costs of the schools.

The intent and language of the [veterans] legislation together with the regulations promulgated thereunder persuade us that Congress did not wish either to legitimize or to underwrite such unscrupulous scheming.

226 F.2d at $165-67$.

136. Hali, Criminal Law ch. 2 (1947); Williams, Criminal Law ch. 12 (1953); cases cited note 127 supra; Lambert v. California, 355 U.S. 225, 22S-29 (1957) ; Screws v. United States, 325 U.S. 91, $101-02$ (1945) ; see Commonwealth v. Donoghue, $250 \mathrm{Ky} .343$, 358,63 S.W.2d 3, 9 (1933) (dissenting opinion) (discussing the ex post facto nature of conspiracy when it is construed to reach conduct not criminal at the time of its commission); Sayre, Criminal Conspiracy, 35 Harv. L. Rev. 393, 413 (1922). Contrast with the basic western approach that of the doctrine of analogy, which explicitly sanctions extensions beyond the bounds of even the most liberal statutory interpretation and which was at one time very much in vogue in fascist and communist countries. See Note, Use 
several sources, some of which spring from the struggle for legislative supremacy and the faith in democracy implicit in that struggle.

But perhaps the most important source is the definition of crime as encompassing mens rea. ${ }^{137}$ That concept represents the historic attempt of the criminal law to ensure that the offender is possessed of a state of mind which makes him deserving of blame and, hence, punishment. Whether this state of mind is found in intent or in some form of negligence, it depends upon the ability of the offender to anticipate the range of consequences likely to follow from action and to guard against, or refrain from, behavior likely to produce those consequences. The underlying assumption is utilitarian: that men are capable of choosing between alternative courses of conduct and that, in a significant number of cases, the threat of punishment will cause them to choose the lawful rather than the prohibited course.

Underlying this assumption is a second and perhaps more questionable assumption-that all men know the law (for, if they do not know it, how can they be deterred?). Thus far, knowledge has been imputed under what is, in essence, a doctrine of constructive notice. The denial of ignorance of law as a defense rests upon the premise that the state has discharged its obligation by drafting a clearly defined statute reasonably available to those who would heed its warning. ${ }^{138}$ Opportunity for knowledge, and the attendant ability to make a reasoned choice, exist and need only be utilized.

Statutes cast in terms meaningful to men of "common intelligence" quite obviously discharge the notice-giving function assigned to them. The same is true of most crimes defined by words of "settled meaning." Those words ordinarily refer to conduct so clearly and so long condemned by the mores that reasonable men have come to know its outlines comparatively well. ${ }^{139}$ But what of conduct falling within terms of supposedly "settled meaning" but not clearly prohibited by the mores? Or prohibited by the mores of one subgroup within a culture but not of another? Or, indeed, conduct permitted by the mores? Quite obviously, as society becomes more complex and as criminal statutes proliferate to include "white collar crimes" and "public welfare offenses," the likelihood that potential offenders actually know what is criminal and what is not-merely because they live in society-becomes increasingly remote. ${ }^{140}$

of Analogy in Crimitual Law, 47 Colum. L. Rev. 613 (1947); MannheIM, Criminal Justice and Social Reconstruction 207-10 (1946). Present indications are that the doctrine of analogy is about to disappear from Soviet legal doctrine. Lipson, The New Face of "Socialist Legality," Problems of Communism, July-Aug. 1958, pp. 22, 25-26.

137. See Williams, Crimiral Law, chs. 2,3 (1953); Hali, Criminal Law, chs. 5, 8 (1947); Hall, Ignorance and llistake in Criminal Law, 33 Ind. L.J. 1 (1957).

138. But see Lambert v. California, 355 U.S. 225, 229 (1957).

139. See, e.g., State v. Buchanan, 5 H. \& J. 317, 359 (Md. 1821) (" $[I] t$ is enough that the offence was known to the lawe before, and if it be malum in se, there is an inward monitor, always present, to warn, advise and instruct."); Connally v. General Constr. Co., 269 U.S. 385, 391 (1926).

140. See the discussion in Hughes, Criminal Omissions, 67 Y $\mathrm{ALE}$ L.J. 590, 615-16 (1958), drawing upon MAYER, RECHTSNORMEN UND KuLturNORMEN (1903). 
One can only surmise, of course, how many persons about to engage in conduct at or beyond the periphery of what is permissible are deterred from doing so by the threat of penalties contained in criminal statutes. ${ }^{141}$ It is quite reasonable to assume, however, that the further away the conduct is from violence, the more rational (and the more deterrable) is the offender to be dealt with. Certainly, those who agree to defraud are likely to be such men. Though it is possible that they will take precise definition as an invitation to evade, it is equally possible that adequate notice of the nature of the prohibited conduct will deter them from pursuing it. Whatever the precise balance between these views, our system of criminal law is built upon the faith that men are rational and that a vaguely drawn statute will not give the potential offender his last clear chance to refrain from criminal conduct.

Precise definition serves other, equally important, ends. Nothing teaches better than the evolution of "defraud" the extent to which such a phrase invests police and prosecutor with a license to interfere with freedom of action in ways unanticipated by the legislature. Definition tends, therefore, to keep the power of arrest and of indictment within bounds and thereby to minimize discriminatory application of the criminal law. It also helps prevent tactical considerations from unduly influencing the trial process-something particularly likely to occur in a conspiracy trial-by furnishing standards to which prosecution and defense may look in preparing a case for trial; by affording the trial judge a manageable criterion for determining the relevance of evidence; and by permitting meaningful instructions to be given to the jury. ${ }^{142}$

There is still another reason for precise definition, one even more peculiarly associated with the intricacies of the conspiracy prosecution. Because conspiracy is a crime which may continue over a long period of time, each new act pursuant to the original agreement extending its life, ${ }^{143}$ it affords the over-

141. Nor can we measure the improvement in the general security of mankind which may follow from specific indications of what may be done.

142. The sixth amendment and the due process clauses of the fifth and fourteenth amendments provide the constitutional guide-lines for the requirement of definition, though considerable support is also to be found in common law and statute. See cases cited note 127 supra; Cole v. Arkansas, 333 U.S. 196, 201 (1948) ; Berger v. United States, 295 U.S. 78, 82 (1935) ; United States v. Cruikshank, 92 U.S. 542, 557-58 (1875); Williams v. United States, 164 F.2d 302, 304 (5th Cir. 1947) ; Williams v. United States, 131 F.2d 21, 23 (D.C. Cir. 1942) ; McMullen v. United States, 96 F.2d 574, 579 (D.C. Cir. 1938). The importance of "real notice" to the defendant is sometimes particularly emphasized in cases involving a defense made without counsel, see Smith v. O'Grady, 312 U.S. 329, 333-34 (1941) ; Ammons v. King, 133 F.2d 270, 271-72 (8th Cir. 1943), although the doctrine may be invoked even when defendant is represented by counsel, see Hallman v. United States, 208 F.2d 825 (D.C. Cir. 1953).

143. The conspiratorial agreement does not end merely because parties are added or eliminated, or because it is to be accomplished in stages over a long period of time, embracing many acts and several violations of criminal statutes. Braverman v. United States, 317 U.S. 49, 52-54 (1942) ; United States v. Kissel, 218 U.S. 601,607 (1910); May v. United States, 175 F.2d 994, 1002 (D.C. Cir.), cert. denied, 338 U.S. $\$ 30$ (1949); United States v. Mazzochi, 75 F.2d 497, 498 (2d Cir. 1935); Lefco v. United States, 74 F.2d 66, 68-69 (3d Cir. 1934); cf. Ex parte Snow, 120 U.S. 274, 281, 285 (1887). 
zealous prosecutor a unique invitation to by-pass prohibitions against double jeopardy. By the simple expedient of assigning different beginning dates to parts of what is really one conspiracy and attaching different sets of overt acts to each of these parts, he may create the illusion that that is discrete which is, in law, continuous. ${ }^{144}$ The defendant is then faced with the almost impossible burden of demonstrating that the events, in fact, flow from a single agreement. Conspiracy to defraud the United States, built as it is upon circumstantial evidence and dependent for its meaning upon a vaguely defined object, lends itself to this type of problem, and to another as well. Even when no great multiplicity of acts or objects is involved, the imprecision of "defraud" enables the prosecutor to argue with ease that much of the evidence he offers to prove an "offense" (a false statement or bribe, for example,) is also admissible to prove "defraud." Facts viewed against the latter standard always appear to disclose a plan that is somewhat different from that revealed under the former. ${ }^{145}$ Since that difference will probably satisfy the prevailing "same evidence" test

144. Considerable analysis and searching of two trial records may be required in order to determine whether an alleged conspiracy $A$ is really the same, or part of, conspiracy $B$. It may even become necessary to submit the issue to the jury. Short v. United States, 91 F.2d 614, 619-25 (4th Cir. 1937). If conspiracy $A$ can be demonstrated to be part of, or identical with, conspiracy $B$, then conviction or acquittal of one would appear to bar prosecution for the other. Similarly, if both are charged as separate counts in a single indictment and conviction on both ensues, there can properly be a sentence on only one of the counts. United States v. Cohen, 197 F.2d 26, 29 (3d Cir. 1952); United States v. Anderson, 101 F.2d 325, 333 (7th Cir.), cert. denied, 307 U.S. 625 (1939); United States v. Mazzochi, 75 F.2d 497-98 (2d Cir. 1935) ; Bertsch v. Snook, 36 F.2d 155, 156 (5th Cir. 1929) ; Powe v. United States, 11 F.2d 598, 599 (5th Cir. 1926) ; Murphy v. United States, 285 Fed. S01, 817 (7th Cir.), cert. denied, 261 U.S. 617 (1923); United States v. Weiss, 293 Fed. 992, 994 (N.D. Ill. 1923). It is not clear whether acquittal of conspiracy $A$ because of insufficiency of evidence (at the close of the prosecution's case) will bar conviction of conspiracy $B$, charged in a separate count of the same indictment. United States v. Klein, 247 F.2d 908, 919 (2d Cir. 1957), cert. denied, 355 U.S. 924 (1958), suggests that there would be no bar. United States v. Wills, 36 F.2d 855, 856 (3d Cir. 1929), on the other hand, indicates the opposite. Cf. Hughes v. United States, 95 F.2d 538 (5th $\mathrm{Cir} .1938$ ), and consider whether the statement in this case may have overlooked the decision in Dunn v. United States, 284 U.S. 390 (1932).

145. Glasser v. United States, 315 U.S. 60, 66-67 (1942), is typical. In this case the Court, quoting from United States v. Manton, 107 F.2d 834, 839 (2d Cir. 1939), said that it need not consider whether a charge of conspiracy to bribe was prohibited by cases holding that there can be no conspiracy to commit a crime which itself involves concerted action:

The indictment does not charge as a substantive offense the giving or receiving of bribes; nor does it charge a conspiracy to give or accept bribes. It charges a conspiracy to ... defraud the United States, the scheme of resorting to bribery being averred only to be a way of consummating the conspiracy and which, like the use of a gun to effect a conspiracy to murder, is purely ancillary to the substantive offense.

Cf. United States v. Weinberg, 226 F.2d 161, 165 (3d Cir. 1955), quoted note 135 supra; see Bridges v. United States, 346 U.S. 209, 222-24 (1953). 
of double jeopardy, ${ }^{146}$ the constitutional safeguard is likely to prove unavailing as a bar to subsequent indictments or to cumulative sentences.

\section{Some Suggested Solutions}

A number of methods are at hand for attacking the problems raised thus far. First, and most obviously, Congress could, and should, repeal the "defraud" portion of the conspiracy statute. Having outlived the function it served during the infancy of the federal criminal code, it now serves only to confuse, to give the prosecution a tactical advantage and to promote de facto violations of the constitutional prohibitions against vagueness and double jeopardy. Congress is unlikely, however, to repeal a statute so useful to prosecutors, particularly when no influential group exists to press for its abolition. Practically speaking, therefore, only judicial remedies offer some promise of reform. At one end of the scale, a de minimis concept might be introduced to enable courts to dismiss prosecutions for agreements involving inconsequential interferences with the Government. ${ }^{147}$ But this should be only the beginning.

\section{The "Either"-Or" Structure of the Statute}

A more far-reaching solution may be found in the relationship between the "offense" and "defraud" portions of the statute: conspiracy is punishable if it contemplates either an offense against the United States or defrauding the United States. The first part of the conspiracy statute appears to incorporate agreements to commit every substantive crime created by Congress and every act to which Congress has attached a noncriminal penalty. ${ }^{148}$ Frauds which are also offenses could, therefore, be treated exclusively under the first half

146. The applicable rule is that where the same act or transaction constitutes a violation of two distinct statutory provisions, the test to be applied to determine whether there are two offenses or only one, is whether each provision requires proof of an additional fact which the other does not. ... "A single act may be an offense against two statutes; and if each statute requires proof of an additional fact which the other does not, an acquittal or conviction under either statute does not exempt the defendant from prosecution and punishment under the other."

Blockburger v. United States, 284 U.S. 299, 304 (1932). The test thus depends upon whether the statute requires the additional proof, not upon whether the same proof happens to be made in a given case. Morgan v. Devine, 237 U.S. 632, 641 (1915); Gavieres v. United States, 220 U.S. 338, 343 (1911) ; Ex parte Nielsen, 131 U.S. 176, 187-89 (1889) ; Short v. United States, 91 F.2d 614, 622 (4th Cir. 1937). But compare the approach of Donnercy, Code of Correction for the Commonwealte of Puerto Rico $\$ \$ 41-45$ (Preliminary Draft, July 1957).

147. Compare the Hawaii conspiracy statute quoted in International Longshoremen's Union v. Ackerman, 82 F. Supp. 65, 104 n.70 (D. Hawaii 1949), rev'd, 187 F.2d 860 (9th Cir. 1951) ("On a prosecution for conspiracy, if the jury find, or the magistrate having jurisdiction of the fact consider, the offense to be trivial, the defendants shall be discharged. ..."). See also the general de minimis provision proposed by DoNNenLY, op. cit. supra note $146, \S 62$.

148. See note 23 sipra. 
of the statute. The second half would then apply only to those frauds which are not denominated offenses by legislation other than the conspiracy statute. Conspiracy to defraud the United States could thus be restricted to those agreements which have as their object the perpetration of frauds upon the Government, and which are not subject to penalty when one person alone is involved, even if that person accomplishes his purpose.

If the two parts of the statute were so read-as mutually exclusive, the more specifically defined section to be applied if at all possible-the structure of the statute would be given effect and, at the same time, there would be an end to cloaking specific offenses with the mantle of fraud. Prosecutions would be brought either for conspiracy to commit an offense or for conspiracy to defraud, but for the latter only under circumstances in which no "offense" (or cluster of "offenses") covered the conduct in question.

The cases lend some support to the suggested reading of the statute. They say, for example, that it creates one offense, not two ${ }^{149}$ - that the allegation of a single agreement having several objects does not give rise to as many conspiracies as there are objects. ${ }^{150}$ Unless considerable weight was given the "either-or" structure of the general conspiracy statute, these decisions might well have accorded with the construction given the two conspiracy provisions of the Sherman Act. Under the latter, the same set of facts, evidencing a single agreement, may give rise to two offenses punishable cumulatively at the discretion of the trial judge. ${ }^{151}$ The reason given is that congressional enactment of two separate conspiracy provisions-one barring agreements in restraint of trade, the other agreements to monopolize, each of which hypothetically requires an element of proof different from the other-demonstrates an intention to create two crimes, to permit two prosecutions and to impose two sentences. Such a position could easily have been taken under the general conspiracy statute, since the "fraud" part of it theoretically requires an element the "offense" portion does not. The fact that the cases arising under the general statute have avoided any multiplication of offense categories lends inferential support to a construction of the statute's two clauses as mutually exclusive.

When these arguments for an alternative reading are viewed in terms of the unique function which the general conspiracy statute has served in the federal

149. May v. United States, 175 F.2d 994, 1002 (D.C. Cir.), cert. denied, 338 U.S. 830 (1949); United States v. Manton, 107 F.2d 834, 838 (2d Cir. 1938), cert. denied, 309 U.S. 664 (1940) ; see Levitt, Duplicity in Indictments Brought Under Section 37, Criminal Code of the United States, 6 ILI. L.Q. 135, 135-36, 144 (1923); cf. State v. Hartung, 239 Iowa 414, 428, 30 N.W.2d 491, 499 (1948).

150. Cf. Braverman v. United States, 317 U.S. 49, 53 (1942); note 143 supra.

151. E.g., American Tobacco Co. v. United States, 328 U.S. 781, 787-88 (1946); Montrose Lumber Co. v. United States, 124 F.2d 573, 575 (10th Cir. 1941); United States v. Buchalter, \&s F.2d 625, 628 (2d Cir.), cert. denied, 301 U.S. 708 (1937); cf. United States v. Samuel Dunkel \& Co., 184 F.2d 894, 897 (2d Cir. 1950), cert. denied, 340 U.S. 930 (1951) (note that the conspiracy to defraud was charged under what is now 18 U.S.C. $\$ 371$ (1952); whereas the conspiracy to obtain payment by a false claim was charged under what is presently 18 U.S.C. $\$ 286$ rather than under the "offense" portion of $\$ 371)$. 
criminal code, a meaningful pattern begins to emerge. The "defraud" language was used early in the statute's history primarily to reach conduct which fell outside the "ordinary" meaning of fraud but which had not yet been made an "offense" by Congress. Operationally, then, the "defraud" portion of the statute has served as an interim measure protecting the Government until such time as Congress has been able to deal more specifically with a given problem. ${ }^{161 a}$ If the statute were now read as it has in fact been applied, courts would find in its alternative structure a means of checking the growth of the "defraud" portion. This reading would treat the congressional creation of a specific offense out of conduct previously reachable only if termed "defrauding" as an expression of legislative intent to remove the conduct from the category of "defraud."

Identical ends could be attained by invoking the doctrine of pro tanto repeal by implication, a doctrine which is, essentially, a rule of statutory construction. ${ }^{152}$ It operates to assign each new piece of legislation an appropriate place in the body of statutes, to erase those parts of older statutes overlapped by more recent provisions, and to leave only such portions of the old as are not

151a. An excellent illustration of the process described in the text may be found in the uses to which $\$ 371$ was put by enforcement officers of the OPA during World War II. They described conspiracy to defraud the United States as:

[A] type of conspiracy [which] arose frequently prior to the passage of the Second War Powers Act when there was no criminal penalty for violations of the Tire Rationing Regulations. In such cases, where it could be established that two or more persons agreed to transfer tires without rationing certificates and in effecting the transfers falsified records or performed some other acts of a deceitful nature to achieve the transfer of tires without certificates a conspiracy to defraud the United States came into being. Other cases falling within the same class arose during the time the gas rationing regulations failed to define ration coupons as property of the United States and also failed to define a transfer properly. During this period groups of persons obtained ration coupons unlawfully and transferred them for profit. Because of the deficiencies of the regulations, neither the improper acquisition nor the transfers constituted "offenses." However, where it could be established that the acts were the result of an agreement, a conviction for a conspiracy to defraud the United States could be sustained. It is well settled that the defrauding meant by the statute is not only pecuniary loss, but also any defeat of a lawful Government function. The only limitation on this rule is that the acts committed must be accompanied by deceit or similar elements of cheating.

OPA Basic Manual for Enforcement Investigators 45 (1944).

152. The doctrine may take one of two forms. A statute may be held to have repealed an earlier statute completely. Or, more often, when the overlap between the old and new statutes is partial, the earlier is considered to be repealed by the later only to the extent of the inconsistency between them. See Terminal Warehouse Co. v. Pennsylvania R.R., 297 U.S. 500, 513-14 (1936) ; United States Nav. Co. v. Cunard S.S. Co., 284 U.S. 474-85 (1932) ; Pennsylvania Water \& Power Co. v. FPC, 193 F.2d 230, 235 (D.C. Cir. 1951), aff'd, 343 U.S. 414 (1952) ; United States v. Eisler, 75 F. Supp. 634, 637-38 (D.D.C. 1947), cert. denied, 337 U.S. 958 (1949) ; Note, The Rosenberg Case, 54 Colun. L. REv. 219 (1954). This note points out that the cases dealing with repeal by implication "are so limited in precedent value and the criteria for resolving the problem so vague that the results of most inquiries are extremely inconclusive." Id. at 248. "An examination of more than 200 federal cases in which repeal by implication was in issue reveals that 
reached by the new. Under this doctrine, the scope of conspiracy to defraud the United States would narrow, for example, the moment an income-taxevasion statute was enacted: a conspiracy to defraud the Treasury of income taxes would no longer violate the "defraud" portion of the statute; it would violate only the "offense" portion. True, the courts have said time and again that repeals by implication are not favored, that they constitute judicial usurpation of a legislative prerogative. ${ }^{153}$ But finding a statute to have been repealed by implication may be essential to prevent continued abdication of the judiciary's constitutional function in the double-jeopardy field. The courts' traditional measure of the prohibition against double jeopardy, the "same evidence" test, finds the constitutional guarantee honored so long as Congress adds a hypothetically different element of proof to an existing criminal category. ${ }^{154}$ Thus, if a general prohibition against false statements does not require that untrue information given to the Internal Revenue Department have any impact on the ascertainment of tax liability, and if, under the separate offense of income tax evasion, such a prejudicial effect must be shown, the fact that the identical false statement is charged in each case will not bar two prosecutions, two convictions and two sentences. 155 Similarly, "commit any offense" and "defraud the United States" are, in theory, different enough to allow two separate prosecutions, although-as when false statements are involved-proof offered in both prosecutions might well be identical. Currently, the only limits on this result are the inadequate ones to be found in the cases dealing with res judicata and cruel and unusual punishment. 156

Nonetheless, absent express legislation to the contrary, it seems unreasonable to assume that Congress regularly intends to pile one penalty upon another already established for substantially similar conduct or directed at a substantially

repeal was effected thirty times [citing the thirty cases]." Id. at 251 n.175. See also Note, Repeal by Implication, 55 CoLuns. L. Rev. 1039 (1955).

Sometimes the formula for adjustment between overlapping statutes is cast in terms of specificity prevailing over generality, regardless of which came first. United States v. Hess, 71 F.2d 78, 79 (Sth Cir. 1934). Illustrative of some of the problems posed by overlapping statutes are Achilli v. United States, 353 U.S. 373 (1957); Berra v. United States, 351 U.S. 131 (1956) (see especially the dissenting opinion of Black, J., id. at 135).

153. See Rosenberg v. United States, 346 U.S. 273, 294 (1953) (concurring opinion of Clark, J.) ; Georgia v. Pennsylvania R.R., 324 U.S. 439, 456-57 (1945) ; United States v. Borden Co., 30 S U.S. 188, $198-99$ (1939) ; United States v. Noveck, 273 U.S. 202 (1927). But cf. Callahan v. United States, 285 U.S. 515, 518 (1932); United States v. Yuginovich, 256 U.S. 450, $462-64$ (1921).

154. Note 146 supra.

155. Cf. United States v. Beacon Brass Co., 344 U.S. 43, $45-54$ (1952) ; Spies v. United States, 317 U.S. 492, 499 (1943).

156. For application of res judicata (or collateral estoppel) to criminal law, see Sealfon v. United States, 332 U.S. 575, 578 (1948); Lugar, Criminal Law, Double Jcopardy and Res Judicata, 39 Iowa L. Rev. 317, 329-44 (1954); Kirchheimer, supra note 124, at 532-33; Developments in the Laz-Res Judicata, 65 HARv. L. REv. 818, 874-78 (1952) ; Annot, 147 A.L.R. 991 (1943). For discussion of the eighth amendment's prohibition against cruel and unusual punishment, see Louisiana ex rel. Francis v. Resweber, 329 U.S. 459 (1947) ; Trop v. Dulles, 356 U.S. 86, 99-104 (1958). 
similar evil. Far more logical and far more consistent with the moral considerations implicit in double jeopardy ${ }^{157}$ is the rule of construction that, when the legislature deals more specifically than in the past with a given kind of antisocial conduct, it intends the new enactment to supersede the old standard of criminality and the old penalty attached to it, at least to the extent that the new covers the same area as the old.

Reading such an intent into the conspiracy statute would produce a result substantially identical with that of the "operational" interpretation previously described. The threat of sanction would still attend the entire range of fraudulent plans directed against the Government. In each case, however, the determination would have to be made whether, on the facts at hand, Congress had dealt specifically with the subject-matter of the conspiracy. If it had, then the "defraud" provision could not be applied and prosecution would have to be brought under the "offense" portion of the statute. The focus of judicial inquiry would be placed squarely where it belongs-on congressional intent and the harm sought to be reached by the legislature. ${ }^{158}$

A number of procedural devices would help implement this approach. To ensure that what is charged under the second half of the conspiracy statute could not have been charged under the first half, courts should invoke the principle that, if the object of the conspiracy is not a substantive crime, the indictment must set forth the allegedly unlawful purpose with the utmost particularity. ${ }^{150}$ Ad-

157. See Note, 65 Y

158. See generally authorities cited note 124 supra.

159. The "void for vagueness" doctrine seems to have made its appearance as part of the due process clauses of the fifth and fourteenth amendments in the early part of the twentieth century. See note 127 supra. Before that time, what might today be classed as an unconstitutionally vague statute was sometimes saved by requiring the Government to specify in the indictment the kind of conduct alleged to be criminal. This satisfied the sixth amendment, which is concerned only with the notice-giving function of the indictment. See, e.g., United States v. Cruikshank, 92 U.S. 542, 558-59 (1875) :

It is an elementary principle of criminal pleading, that where the definition of an offense, whether it be common law or by statute, includes generic terms, it is not sufficient that the indictment shall charge the offense in the same generic terms as in the definition; but it must state the species,-it must descend to particulars. Id. at 558. Where the crime charged in the indictment was conspiracy for a criminal purpose, it sufficed to state the purpose, "while if the criminality of the offense consists in the agreement to accomplish a purpose not in itself criminal or unlawful, by criminal or unlawful means, the means must be set out." Pettibone v. United States, 148 U.S. 197, 203 (1S93); accord, United States v. Atlanta Journal Co., 185 Fed. 656, 662-63 (C.C.D. Ga. 1910), appeal dismissed, 229 U.S. 605 (1913) ; United States v. Walsh, 28 Fed. Cas. 394, 396 (No. 16636) (C.C.E.D. Mo. 1878) ; Commonwealth v. Eastman, 55 Mass. 189, 203-06 (1848) ; Commonwealth v. Hunt, 45 Mass. 111, 125-26 (1842).

The suggestion in the text is somewhat at odds with Williams v. United States, 168 U.S. 382 (1897), which holds that a person may be convicted of a crime even if the statutory citation in the indictment is to a different crime: "[If the indictment] properly charges an offense under the laws of the United States, that is suffcient to sustain it, although the representative of the United States may have supposed that the offense charged was covered by a different statute." $I d$. at 389 . But a condition of the Williams doctrine is that the indictment put the accused on notice of the offense he must meet at trial. 
ditional specificity could be attained if bills of particulars were granted more freely in this class of case. Finally, upon challenge of defense counsel that a charge brought under "defraud" should have been brought under the more specific "offense" portion of the statute, prosecutors should be required to explain to the court why the more specific statute was not used-and, if necessary, to support the explanation with an offer of proof. If the indictment and particulars, thus amplified, should disclose that the purpose of the conspiracy was to violate one or more substantive criminal laws, the trial would proceed under the "offense"-not the "defraud"-portion of the statute.

If, on the other hand, the specific violations were not disclosed by the prosecutor at the outset but the evidence subsequently offered did fit within conspiracy to commit an "offense," alternative approaches could be taken. Evidence offered to prove the specific offense might be excluded-either because it departed from the indictment and the bill of particulars ${ }^{160}$ or because admitting it would run counter to the spirit underlying the double-jeopardy provision of the Constitution. Such exclusion of evidence, could, of course, result in a judgment of acquittal at the close of the prosecution's case because of insufficiency of evidence. But no reason appears why a judgment adverse to the Government should not be entered in the type of case in which exclusion would mean acquittal-one in which the prosecutor could produce little evidence other than that of a specific offense to substantiate his "defraud" charge. What of the prosecutor who allegedly did not know prior to trial that his evidence would support a theory entirely different from that pleaded in the indictment or set out in a bill of particulars? This problem could be treated as are variances generally - with the inquiry focused upon whether the error affected the proceedings ${ }^{161}$ and whether it was made in good faith or was deliberately designed to gain tactical advantage.

The alternative construction theory cannot by any means be described as a panacea. The sheer bulk and complexity of the federal criminal code make it impossible to chart the precise points at which "offense" and "defraud" overlap and to say what would be left of "defraud" were the overlap eliminated. Nevertheless, some guesses may be hazarded. Since there is no general offense of "defrauding the Untied States," except when two persons, in agreement, intend it, ${ }^{102}$ the coexistence of "offense" and "defraud" as alternative objects of

160. The usual rule is that the prosecution is limited in its proof by the bill of particulars and may not depart from it. United States v. Neff, 212 F.2d 297, 309-10 (3d Cir. 1954); Bryan v. United States, 175 F.2d 223, 237 (5th Cir. 1949), aff'd, 338 U.S. 552 (1950); United States v. Adams Express Co., 119 Fed. 240, 242 (S.D. Iowa 1902). Of course, whether or not a given item of evidence departs from the bill of particulars is itself a question which may be answered with varying degrees of liberality. And the same is true of the question whether overt acts may be proved which are not set out in either indictment or bill of particulars.

161. See Kotteakos v. United States, 328 U.S. 750 (1946) ; Berger v. United States, 295 U.S. 78, 81-84 (1935); United States v. Liss, 137 F.2d 995, 1003-05 (2d Cir.) (dissenting opinion of Frank, J.), cert. denied, 320 U.S. 773 (1943).

162. There are, of course, statutes punishing individuals for specified frauds. See notes $114-15,117-18$ supra. 
conspiracy would require that conspiracy to "defraud" always reach something more than conspiracy to commit an "offense."163 If all frauds were found to have been made offenses, the second part of the conspiracy statute would then have no reason for being-as might indeed prove to be the case. Preliminary testing of certain obvious areas of overlap does reveal, however, that some scope would be left for "defraud." For example, conspiracy to defraud the United States would seem to reach more than conspiracy to commit the offense of filing a false claim. ${ }^{164}$ A fraudulent scheme may well involve overreaching government by means other than the filing of a claim. Though it is not as clear that conspiracy to defraud would reach more than conspiracy to commit the offense of filing a false statement-since the language of the false statement provision, section 1001 of title 18, reaches not only affirmative misstatements but also willful failure to speak ${ }^{165}$ - the cases brought under section 1001 seem invariably to involve the filing of a document or the making of a statement to a particular government official. None predicate liability upon concealment in the absence of a statutory obligation to disclose or of some direct-dealing relationship between the defendant and the Government. And virtually none involve nondisclosure except when it accompanies some submission of data. ${ }^{166}$ A residuum of "frauds" falling outside the usual category of "false statements" would therefore seem to be probable. In addition, other types of misconduct not even remotely within the scope of a conspiracy to violate section 1001 might be reached by conspiracy "to defraud the United States.” Inducing a telephone call by a highly placed government official in order to obtain information out of the regular course of government business is one example. Agreeing to interfere with the efficient operation of the Government by means other than falsehood is, of course, another.

The types of conduct that would be covered only under "defraud" thus appear to be precisely those which the conspiracy law ought least to reach in the absence of specific legislation. Certainly, then, in enforcing an alternative con-

163. See e.g., Glasser v. United States, 315 U.S. 60, 66-67 (1941); United States v. Furer, 47 F. Supp. 402, 405 (S.D. Cal. 1942).

164. See 18 U.S.C. $\$ \$ 286,287$ (1952). Note that $\$ 286$ prohibits, inter alia, "conspiracy to defraud the United States . . . by obtaining . . . the payment or allowance of any false, fictitious or fraudulent claim. ..." This illustrates the problem discussed in the text accompanying notes $149-51$ supra. Does $\$ 286$ create an offense additional to that contemplated in the second half of the conspiracy statute? Additional to a charge, brought under the first half of $\S 371$, of conspiracy to violate $\S 287$ (the substantive false claim statute) ? Additional to conspiracy to violate $\$ 1001$ (the general false statement statute)?

165. See the broad construction given the forerunner of 18 U.S.C. $\$ 1001$ (1952) in United States v. Gilliland, 312 U.S. 86, 93 (1941) (Congress intended "to protect the authorized functions of governmental departments and agencies from the perversion which might result from the deceptive practices described [i.e., false and fraudulent statements]."). Compare the admonition of the trial judge in the same case, warning against the adoption of a construction tied so loosely to the "operations of the innumerable and ever growing departments, bureaus, and agencies of the Government." United States v. Gilliland, 35 F. Supp. 181, 187 (E.D. Tex. 1940).

166. See the annotations to 18 U.S.C.A. § 1001 (Supp. 1957). 
struction of the statute, any tendency to give "defraud" a content outside its "ordinary" meaning ought to be restrained. To do otherwise would be to invite a repetition of the error which has already plagued this statute. A more appropriate procedure would be to sit back and await the outcome of a caseby-case application of the alternative theory. Eventually, the portions of "defraud" that had not been absorbed by the creation of "offenses" would be disclosed.

Application of the alternative theory would be likely to accomplish even more. By eliminating too easy reliance on the substantive offenses as a means of supplying content to "defraud," it would gradually succeed in forcing a closer definition of the kinds of deceit and dishonesty contemplated by Hammerschmidt. Furthermore, to the extent that this approach would channel the prosecution of clusters of offenses toward the first half of the statute, it would focus the attention and energy of court and jury on that which is definable rather than on a scheme so large or so abstruse that it must be cloaked under the catch-all of fraud. ${ }^{167}$

\section{A Core of Meaning For "Defraud the United States"}

If the alternative theory of the statute, set out above, is not adopted, the question would remain whether the words "defraud the United States" can be given a more restrictive and more meaningful construction than that offered by Chief Justice Taft in Hammerschmidt. A reading that imposes an obligation to deal honestly with government is too broad to be understood either by reasonable men or unreasonable public officials. The only guide lines which are likely to stand the test of time and serve the needs both of the man of "common intelligence" and of the trial process are those to be found in the "ordinary" or "legal" meaning which the phrase enjoyed until $T y n e r$ began the movement toward "equitable" fraud. That "ordinary" meaning would endow "defrauding" with two minimal characteristics: first, there must be a falsehood, a lie; second, the lie must be purposive in nature. ${ }^{168}$ Thus, a bribe which accom-

167. Even if "defraud the United States" is not held to be repealed by more specific "offenses," there would seem to be every reason to instruct the jury as to the elements of the "offenses" which happen to be involved in a conspiracy to defraud the United States. Cf. Williams v. United States, 131 F.2d 21, 23 (D.C. Cir. 1942).

168. The core of the idea of fraud in the discreet sense is deception, i.e., mistake for which the other party is knowingly responsible. ... [T] defined in the Restatement [of Contracts, $\S 471$; of Restitution $\$ 8$ ] ... [involves] conscious misrepresentation, concealment or unprivileged nondisclosure with the intent to mislead the other party into entering into or refraining from entering into a transaction.

Green, Fraud, Undue Influence and Mental Incompetency, 43 CoLUM. L. REv. 176, 179 (1943). See also note 43 supra; Bigelow, Definition of Fraud, 3 L.Q. REv. 419 (1887).

Conspiracy to defraud appears to have been directed originally at "such an act as would if done by a single person give the person defrauded a civil remedy ... Actual deception must be involved." Digby, The Laze of Criminal Conspiracy in England and Ireland, 6 L.Q. Rev. 129, 132 (1890). 
panied a submission of information in itself accurate, and which was designed to ensure favorable governmental action, would not constitute "fraudulent" conduct. Though the total fact situation would indicate "purposiveness," the first element-the "lie"-would not be present.

Lies involve misrepresentations or the distortion of truth. When communicated to others by speech or conduct, they pose no substantial problems of definition, although peripheral difficulties may arise when the subject of the communication is an opinion or a future event. ${ }^{169}$ The beginning of a problem emerges when someone fails to communicate information in a setting in which the information is asked for and, if not supplied, will distort the picture being presented to the Government. In such circumstances, however, the failure to disclose is coupled with incomplete documents or statements which purport to disclose all the facts. The total submission may therefore be described as an affirmative misstatement which affords a basis for judgment.

A more difficult problem can arise when the law does not specify what must be disclosed to the Government by an individual and when no questions are directed at him. Should criminal liability follow from a mere failure to come forward and volunteer information? The conventional answer is that silence constitutes falsehood, and that liability may be imposed, only if the circumstances call for speech, for warning or for facts. It is, essentially, the approach of the law of criminal omissions ${ }^{170}$ and serves to introduce the second minimal requirement of fraud, that of purposiveness.

Both the affirmative misstatement and the failure to speak must be cast in a setting where he who speaks or remains silent is thereby seeking to gain an advantage over the Government or its representative in some transaction between them. In short, the very word "defraud" connotes activity. It suggests that the lie (which now embraces nonspeech as well as speech) must be purposive and must spring from a transactional relationship between the would-be defrauder and the Government. There must already have been, or be in prospect, a coming together-whether by mail or in person or by phone-with the defrauder seeking a benefit from the Government which would not be conferred upon him if he revealed the truth. ${ }^{171}$

169. The range of the fraud doctrine is explored, and authorities are cited, in $\mathrm{MICNabb}$ v. Thomas, 190 F.2d 608 (D.C. Cir. 1951) ; Baker v. Baker, 296 Fed. 961,964 (D.C. Cir. 1924). See, in addition, Pearce, Theft by False Promises, 101 U. PA. L. Rev. 967 (1953).

170. See Hughes, Criminal Omissions, 67 YALE L.J. 590 (1958).

171. See United States v. Lepowitch, 318 U.S. 702, 704 (1943) (Under a statute making criminal the impersonation of a federal officer with intent to defraud the United States or any person, "the words 'intent to defraud' ... do not require more than that the defendants have, by artifice and deceit, sought to cause the deceived person to follow some course he would not have pursued but for the deceitful conduct.") ; Palmer v. Colladay, 18 App. D.C. 426, 433 (D.C. Cir. 1901). But see Head v. Hunter, 141 F.2d 449, 451 (10th Cir. 1944) ; United States v. Goldsmith, 68 F.2d 5, 7 (2d Cir. 1933), cert. denied, 291 U.S. 681 (1934), in both of which the requirement that the fraud be directed at the Government is ignored. The emphasis seems to be on the injury to governmental functions which may follow fraudulent conduct directed at private persons. 
To constitute a criminal conspiracy, the fraudulent object, thus defined, should be one which would, in fact, interfere with the functioning of the Government if it were successfully carried out. Unless this last issue is expressly added to the others given to the jury under the "defraud" provision, entirely too great a likelihood exists that injury and interference will be conclusively presumed from the mere fact that the defendant's conduct was morally reprehensible.

Absent some immediate relationship between the would-be defrauder and the Government, there should be no liability for either the lie or the failure to speak at all-unless, of course, the obligation to speak and to disclose has been specifically imposed by Congress. A government as vast as ours simply cannot safely be treated as omnipresent, imposing upon everyone an obligation to volunteer all information having even the remotest bearing upon efficient governmental operations. There would be entirely too much of "Big Brother" in such a requirement and too great an abdication of the legislature's crimecreating power to prosecutor and court.

The kind of betrayal of public trust involved in the Haas case-release of confidential statistics-would not seem to satisfy these minimal requirements. ${ }^{172}$ No falsehood came from outside of the Government to induce it to part with anything. An employee simply did not do his job as he was ordered. No one in Haas sought to hoodwink the Government or to induce it to take action. Benefit in the financial markets was the objective, not benefit from the Government. ${ }^{173}$ Unless the statute is to be read as a blanket proscription against any sharp practice affecting the public interest, a case like Haas should not have been brought within conspiracy to defraud the United States.

Curley, on the other hand, does meet all of the requirements. It involved a proffer by Curley of a civil service examination purportedly written by someone else. A false representation was made in the document and, if acted upon, would have resulted in the Government's paying for something it had not bought. For different reasons, Hammerschmidt was also correctly decided. It involved no face-to-face relationship whatever, actual or potential : the defendant had incited the people at large to disobey the law. No governmental action

172. The reference here is only to the count charging conspiracy to defraud the United States by interfering with a lawful function of government. See note 69 supra.

173. Compare the lower court opinion in Haas v. Henkel, 166 Fed. 621, 626 (C.C.S.D. N.Y. 1909) :

I cannot see that the United States was in any respect defrauded by the publication of these statistics to individuals before the official publication to the country at large. There is no ground for presuming that Congress intended to prevent individuals obtaining information in advance of its general publication. Such persons would, of course, have an advantage in trading in cotton with others who had not that information; but I do not see that the United States would be in any way defrauded, either of its property or its rights. We should not be induced, by our contempt for or indignation at such conduct as is set forth in the indictments, to turn it into a crime if it is not one.

The court did go on, however, to uphold other counts on the theory that the conspiracy charged therein was intended to cause publication by the Government of incorrect reports. 
was sought. Clearly, then, the "purposiveness" element of "defraud" was absent. The Supreme Court did not base its decision on this theory, however, but held instead that open interference with a statutorily expressed policy of the United States could not come within the compass of "defrauding," just as interference by force could not.

In sum, return to the "ordinary" meaning of fraud would go at least part of the way toward eliminating the problems raised by the statutory "defraud" provision. ${ }^{174}$ Nevertheless, if the notion that "defraud" has a hard core of meaning is not coupled with the alternative construction of the statute, it will prove at best an incomplete solution.

\section{Danger From the Group as the Criterion of "Defraud"}

Whether "defraud" is construed narrowly, in accordance with its "ordinary" meaning, or broadly-to reach the new "gimmick" or the planned scheme so complex that it defies advance description-the fact that Congress designed it to operate only when two or more persons were in agreement provides the basis for still a third meaningful approach. A tentative hypothesis would appear to be in order. Conspiracy to defraud the United States was intended to reach those frauds upon the United States which were more likely to be accomplished by two persons than by one. Otherwise, the same conduct would have been made criminal in an individual. This hypothesis is not entirely without support. In some of the early cases involving conspiracy to accomplish a noncriminal object, courts put to themselves the question whether such a conspiracy posed

174. For reaffirmations of the pecuniary or proprietary base of "fraud," at least in certain contexts, see United States v. Cohn, 270 U.S. 339, 345-47 (1926) (rejecting extension of "secondary" meaning of fraud, as stated in Haas and Hammerschmidt, to a statute classing as a criminal "whoever ... for the purpose and with the intent of cheating and swindling or defrauding the Government of the United States . . . shall knowingly and willfully falsify or conceal or cover up by any trick, scheme or device a material fact ...."); United States v. Kushner, 135 F.2d 668, 671 (2d Cir.), cert. dcnicd, 320 U.S. 212 (1943) ("[W] hile this ['revenue,' in a statute prohibiting smuggling into the United States "with intent to defraud the revenue of the United States] may mean the revenue department, thus avoiding the difficulty of defrauding an inanimate thing, yet it seems likely that an actual loss of government income was contemplated .... The Supreme Court has shown a tendency to restrict the broader meaning of defrauding whenever the circumstances suggest, even if they do not state a narrower view."); United States v. Randle, 39 F. Supp. 759, 760 (W.D. La. 1941) (under mail fraud statute, scheme must be one which would deprive persons of money or property of some value, not of civil or political rights). But see United States v. Gilliland, 312 U.S. 86, 93 (1941) (adopting a broader construction of the statute involved in United States v. Cohn, supra, after Congress had eliminated some of the language upon which the Cohn Court had relied in reading the statute narrowly); United States v. Goldsmith, 68 F.2d 5, 7 (2d Cir. 1933) (under statute prohibiting the presentation of false or forged writings for the purpose of defrauding the United States, "pecuniary loss is not necessary; any impairment of the administration of its governmental functions will suffice." [citing Haas v. Henkel]) ; Head v. Hunter, 141 F.2d 449, 451 (10th Cir. 1944); Pina v. United States, 165 F.2d 890, 893-94 (9th Cir. 1948). 
a greater threat to society than an individual planning the same action. .75 $^{7}$ And, on at least three occasions, Congress rejected the suggestion of the Attorney General that frauds against the Government be made criminal when perpetrated by one, as well as when agreed upon by two. ${ }^{176}$ The "group danger" question would seem to frame the issues under the "defraud" provision as they should be framed. It would seize upon the debatable reason for statutory language that is, in fact, too broad and would force that language to meet the test of application to one fact situation after another. Inevitably, the outlines of "fraudulent" conduct would have to be drawn in terms of the functional impact of two or more persons upon an activity which is not considered dangerous in one-on the basis of whether a given result is more likely to be attained when two join in pursuing it than when only a single individual plans the action.

Focusing on group danger as a means of distinguishing the kinds of frauds Congress intended to reach under the second half of the conspiracy statute would seem, at first blush, to be at odds with the statute itself. By prohibiting conspiracy to defraud the United States, Congress would appear to have removed from judge and jury the power to determine that some frauds on the Government exist which are not more dangerous when agreed upon by two

175. E.g., in State v. Dalton, 114 S.W. 1132 (Mo. Ct. App. 1908), defendants were indicted for conspiring to prevent journeymen plumbers from working for master plumbers by demanding money from the latter before permitting the journeymen to work for them. According to the court, the demand for money was an individual tort but not a crime. The combination, however, converted the scheme into a criminal conspiracy. The court's reasoning is of particular interest:

It may be stated as a general proposition that, where an additional power or enhanced ability to accomplish an injurious purpose arises by virtue of the confederation and concert of action, an element of criminal conspiracy is thereby introduced which will render sufficiently criminal either the means or the purpose, otherwise merely unlawful, to sustain a conviction, although the means or the end were not such as are indictable if performed by a single individual. . . . A single individual, acting alone to the same end, would indeed be less bold and more likely to recede from a sense of insecurity in his venture. And then, too, the ability of one person to coerce the subject of his design would be less potent. The additional power and enhanced ability arising from a confederation of two persons to overawe and coerce an ordinary man to part with his means against his will, under the circumstances alleged in the indictment, is obvious.

Id. at 1138-39.

See Commonwealth v. Waterman, 122 Mass. 43,57 (1877) ; State v. Buchanan, 5 H. \& J. 317, 354 (Md. 1821); Fisher v. United States, 2 F.2d 843, 847 (4th Cir.) (dissenting opinion), cert. denied, 266 U.S. 629 (1924); 2 Bishop, CRIMINAL LAW \& 158 (2d ed. 1859). For analogies from the civil tort of conspiracy, see Fughes, The Tort of Conspiracy, 15 Monern L. Rev. 209 (1952) ; Burdick, The Tort of Conspiracy, 8 Colum. L. REv. 117, 118 (1908).

176. In 1910 and again in 1919 and 1920 , the Attorney General recommended to Congress that acts which constitute conspiracy to defraud when done by two or more persons be made substantive offenses when done by an individual. 1910 Atr'y GEN. ANN. ReP. 85; 1919 Atr'y Gen. Ann. Rep. 2; 1920 Att'y Gen. ANn. Rep. 3. 
persons than when accomplished by one. So literal an application of the words of the act fails to explain, however, why Congress has felt it necessary, both before and after enactment of this statute, to make some frauds on the Government "offenses." Of course, one reason may have been to provide additional punishment. But another and equally likely reason, and one which assigns some special function to the "defraud" provision, is that Congress intended to confine its reach to those planned frauds which are of appreciable danger to the community only if agreed upon by at least two persons. The provision was to proscribe fraud in the same way that price-fixing is forbidden. ${ }^{177}$ The added danger from collective action was the raison d'être of the crime.

It would be folly to claim that anything presently in the federal case law suggests that agreements to defraud the United States must involve some special element of group danger. The lie to a government officer, the failure to disclose information to a government agency or the unsuccessful bribe offer certainly do not require the concerted activity of two or more men. All have nevertheless furnished bases for liability under the "defraud" section. Yet, if a criterion for a concededly catch-all statute is to be fashioned without the aid of legislative history, it seems not inappropriate to seek guidance in what proves on analysis to be the reason for the rule. The "group danger" approach would not differ materially from the use made of the "clear and present danger" test for determining when freedom of speech has been impaired.178

The fact situation in Haas illustrates the group-danger concept very well. That case involved a government officer, $A$, in possession of information which might prove useful in speculation on the commodities exchanges. Persons such as $A$ could be deemed so exposed to the risk of corruption that they must be protected at all costs from the blandishments of persons outside government. But why should blandishments by $B$ be punished when he acts pursuant to an agreement with $A$ (or, indeed, with $C$, who is not a government employee) but not when he acts entirely in his own behalf? In both cases, the object is identical-corruption of the official vested with the responsibility of decision. And the means used to persuade the officials are identical. All that differs is the existence of an agreement. Now, an agreement between $B$ and $C$, without $A$ participating, would not appear to facilitate the corruption of $A$, from whom the information must be obtained, any more than if $B$ or $C$ approached $A$ individually. But if $A$ should join with $B$, a different conclusion may be indicated. $A$ is not likely to use the information for his financial advantage because his personal speculation might easily be traced to him. But if he has a confederate to whom he can leak the information and who can use it without calling $A$ 's activities into question, then perhaps confidential statistics are more

177. See United States v. Socony-Vacuum Oil Co., 310 U.S. 150, 223 (1940).

178. See Dennis v. United States, 341 U.S. 494, 511-15 (1951), which holds that it is for the court to determine whether there is a "clear and present danger" of a substantive evil which the legislature has the right to prevent. Justice Douglas, dissenting, suggests that the question should be decided by the jury; and even if decided by the court, "there should be evidence of record on the issue." 341 U.S. at 587. 
likely to be improperly disclosed. Under such circumstances, there may be greater danger to governmental operations from an agreement by two persons than from the plan or the deed of one. Both the government employee's position and his contemplated use of that position suggest that group action in this instance should be treated differently from individual action.

Unfortunately, with a statute as broad as that outlawing conspiracies to defraud the United States, it is impossible to anticipate either the kinds of fact situations to which it will be applied or their amenability to the functional classification suggested. Yet, unless such a classification is attempted, persons may be punished for plans nowhere near execution, while their fellows who, as individuals, have executed schemes equally prejudicial to the community go unpunished. Such an unequal operation of the law may well be assumed to have been outside the expectation of Congress when it drafted the statute. Once again, the expeditious way of accomplishing the task of functional classification would be to proceed on a case-by-case basis. The trial judge would initially determine whether the facts warrant an inference of special danger to the community from group participation in the plan; and, where factual issues presented themselves, would pass them on to the jury. Group danger would thus become as much an element of conspiracy to defraud as intent and agreement and fraud. In view of the large number of prosecutions brought each year under the second half of the statute, group danger would probably become, before long, as manageable a concept as any of the elements of conspiracy already tested by time.

\section{CONCLUSION}

When all the cases have been read, two words, seemingly rich in legal significance, are shown to have done more to unsettle the meaning of the federal conspiracy statute than if completely new language had been used. The breadth of the concept of common-law conspiracy has conditioned the judiciary to tolerate a looseness of interpretation which essentially allows the fact situation to shape the crime. This result has been facilitated by the fact that "defraud" is itself a word which, though possessed of an "ordinary" meaning, has had that meaning obscured and eventually superseded by an unprecedented degree of judicial expansion. The total picture is even more complex because, whatever the resultant of the conspiracy and defraud vectors may be, it is shielded from view by the notion that words known to the common law are possessed of a "settled meaning." Here, the use of such words functions at one and the same time to impart vagueness and yet to satisfy the constitutional test for the definition of crime.

"Conspiracy to defraud the United States" has evolved in several stages. First, it was a crime reaching only agreements to use falsehood to induce action by the Government which would cause it a loss of money or property. It expanded to include an agreed-upon falsehood which might disadvantage the Government in any way whatever, and ultimately covered virtually any impairment of the Government's operating efficiency. The end to be gained having thus been 
obscured, it remained only for the means to be made equally shadowy. This was accomplished in the cases which viewed any dishonest act, including concealment, as the measure of an interference with the Government. Suspiciously unethical conduct, the failure to disclose even that which Congress had never required to be disclosed, became the raw material from which criminal liability was fashioned.

As a result of these interpretations, the federal conspiracy statute has become another governmental weapon in the eternal conflict between authority and the individual. By making unclear the line between what is permitted and what is prohibited, by conceiving the statute's reach to be as broad as that of an expanding government, present doctrine places within the power of police and prosecutor an instrument for intruding upon Everyman. The instrument is all the more dangerous because it wears the garb of conspiracy, with all the tactical and evidentiary benefits that that doctrine implies. Imprecise definition and procedural advantages combine to make it virtually certain that a charge of conspiracy to defraud the United States will get to the jury-where a showing of suspicious behavior by the sort of people who ought to know better and who least appeal to that body's occasional empathy for those who commit crimes of passion and violence, is very likely to produce conviction.

The main point of this Article might well have been that the crime of conspiracy to defraud the United States has outlived its usefulness and that Congress should repeal it. ${ }^{179}$ Repeal is particularly indicated because this is no longer a time when antisocial conduct so outstrips the available criminal categories that a catch-all crime is essential in order to deter persons, particularly at the federal level, from approaching the outer limits of criminality. Indeed, today's detailed federal criminal code reaches so broad a range of antisocial conduct and in such overlapping fashion that multiplicity of categories covering the same conduct, not sparseness of categories, is the central problem. Furthermore, Congress presently sits in almost continuous session, ready to act on recommendations for criminal legislation from the multitude of federal agencies dealing with all aspects of our national life. ${ }^{180}$ The rapidity with which curative legislation can be enacted makes it unlikely that many persons will long escape prosecution for conduct deemed offensive to societal norms.

179. The author's primary concern with conspiracy to "defraud the United States" should not be taken as an implicit indorsement either of the first half of the conspiracy statute, or even of the desirability of including a general crime of conspiracy in the federal code.

180. Virtually all of the major regulatory statutes enacted by Congress contain at least one provision making it a crime "willfully" to violate other provisions of said statutes. In addition, Congress has provided criminal penalties for violation of regulations issued by many administrative officials. Of course, noncriminal sanctions are also available against persons who deal "improperly" with the Government. Not only can the conventional civil remedies be invoked but others as well, e.g., civil fraud penalties under the tax laws, suspension lists and black lists of persons seeking government contracts, and the denial of tax deductibility for various expenditures. 
Nevertheless, repeal of this statute in the near future is unlikely. For those who look upon crime as something to be fought with all the vigor of war, a statute like this one meets a real need. Perhaps this is because the war against crime, like all wars, engenders a flabbiness of principle, a watering down of procedural proprieties. The actors in the unfortunate drama are regularly called upon to respond to conflicting conceptions of what ought to be. The prosecutor who believes fervently in the rule of law seems willing to have it relaxed through the use of devices which shield from him and from his peers the fact that he is doing so. The judge who would not admit to a theory of the judicial process as little more than the manipulation of concepts permits "traditional" doctrines to prevent him from cutting through to the hearts of the problems they veil. And defense counsel, as much a victim as the others in the battle between form and substance, finds it virtually impossible to discover the appropriate referents that will enable him to act out his role.

It will take every bit as much ingenuity to find a way out of the maze as it took unconcern with the larger values of the criminal law and with the usual bounds of statutory definition to enter it. Doctrines must be reshaped with bold strokes and within a much larger frame than has hitherto characterized analysis in this branch of federal criminal law. Until this is done, "conspiracy to defraud the United States" will remain on the books as a Kafkaesque crime, unknown and unknowable except in terms of the facts of each case-and even then, not until the verdict has been handed down. 